\title{
Second Generation Bioethanol from Lignocellulosics: Processing of Hardwood Sulphite Spent Liquor
}

\author{
Daniel L. A. Fernandes, Susana R. Pereira, Luísa S. Serafim, \\ Dmitry V. Evtuguin and Ana M. R. B. Xavier \\ CICECO, Department of Chemistry, University of Aveiro
}

Portugal

\section{Introduction}

The world is facing a reduction of global fossil fuels resources, like petroleum, natural gas, or charcoal, while energy requirements are progressively growing up. Fossil fuels should be replaced, at least partially, by biofuels once the current fuel supply is suspected to be unsustainable in the foreseen future. In fact, the search for sustainable alternatives to produce fuel and chemicals from non-fossil feedstocks has attracted considerable interest around the world, to face the needs of energy supply and to response to climate change issues. Alternative resources of energy are being explored in order to reduce oil dependence and increase energy production by exploring of solar, wind, hydraulic and other natural phenomena. Besides these sources of energy, also biomass possesses a potential target for fuel and power production as well as for chemicals or materials feedstocks. Thus biomass can efficiently replace petroleum-based fuels for a long term. (Sanchez et al. 2008; AlvaradoMorales et al. 2009; Brehmer et al. 2009; Gonzalez-Garcia et al. 2009; Singhania et al. 2009; Mussatto et al. 2010; Sannigrahi et al. 2010).

Many countries in Europe, North and South America and Asia are replacing fossil fuels by biomass-based fuels according to international regulations. One of the directives of European Union (2009/28/CE) imposes a quota of $10 \%$ for biofuels on all traffic fuel until 2020 (Rutz et al. 2008; Xavier et al. 2010). Also economic incentives for research on biofuels are being implemented all over the world. Bioethanol can be produced from different raw materials containing simple sugars, starch or more complex substrates as lignocellulosics. New methodologies for biofuels (e.g. ethanol and biodiesel) production have been developed in the last years, to achieve new and non cost-intensive technologies for bioconversion of lignocellulosic renewable resources. The most common renewable fuel is ethanol, which is produced from direct fermentation of sugars (e.g. from sucrose of sugarcane or sugar beet) or polysaccharides (e.g. starch from corn and wheat grains) (Gonzalez-Garcia et al. 2009; Mussatto et al. 2010). The selection of the best raw material is strongly dependent on the local conditions where feedstock is obtained. Evidently, ethanol in Brazil is produced from sugarcane, whereas, in North America or Europe the ethanol industry is based on starchy materials. Besides, energy considerations should be attained: not only the energy input required for ethanol production and the content in fermentable 
sugars of the feedstock must be considered, but also the annual ethanol yield per cultivated hectare. As suggested, for beet molasses, the yield of ethanol per ton of feedstock is lower than that for corn, but on the other hand, when compared to starchy materials the beet productivity per cultivated hectare, expressed in L/(ha year), is considerably higher, (Sanchez et al. 2008).

The growth of the biofuels industry raised questions regarding the sustainability of these "first generation" biofuels. The feedstocks described play an essential role in human and animal food chains, therefore the rise of prices of food all over the world resulted in social disturbance (Gonzalez-Garcia et al. 2009; Mussatto et al. 2010; Xavier et al. 2010). These raw materials were also expected to be limited due to the reassign of arable lands from food to fuel production leading to competition for feedstocks (Gray et al. 2006; Bacovsky et al. 2010). Moreover, first generation biofuels were accused of not contributing to reduce gas emissions, therefore the use of this technology was highly criticized. For all these reasons additional research in this area is mandatory, in order to search for non-food crops, like wastes from agriculture and/or industry as sources of raw-material. European Union strongly incentives research focusing biotechnological solutions for energy and chemical demands from renewable resources, such as, forestry wastes, agricultural biomass residues and food industrial wastes for "second generation" biofuels production.

The great advantage for the choice of lignocellulosic biomass as feedstock is the noninterference with food chain, which allows the production of bioethanol without using arable lands (Sanchez et al. 2008; Zhang 2008). Lignocellulosic biomass is a complex raw material which can be processed in different ways to obtain other value-added compounds contributing to the possibility of establishing a biorefinery. Different value-added products such as lactic acid, acetic acid, furfural, methanol, hydrogen and many other products can be obtained from its sugars. Lignin, the non-carbohydrate component, can be used for the production of advanced materials, polymers and aromatic aldehydes (Sanchez et al. 2008; Zhang 2008; Sannigrahi et al. 2010; Santos et al. 2001). In this way, lignocellulosic biomass can be used as substrate for the production of second generation biofuels, contributing to the diversification of energy supply and gas mitigation, offering less competition for the food and feed industry (Rutz et al. 2008; Bacovsky et al. 2010). The use of these raw materials to produce fuel, power and value-added chemicals, fits well into the biorefinery concept invoked to decrease the dependence from fossil resources and to improve the economic sustainability (Alvarado-Morales et al. 2009; Xavier et al. 2010). However, for a world massive utilization of fuel ethanol, a cost-effective technology for ethanol production is also required. In other words, ethanol production costs should be lowered (Sanchez et al. 2008). In a biorefinery, different technologies, including fermentation, biocatalytic, thermal and chemical technologies, must be used simultaneously for biomass conversion for the production and the purification of different value-added products (Alvarado-Morales et al. 2009).

Bioethanol is one of the products that can be obtained via biorefinery using bio-based resources. It is one of the most attractive biofuels, since it can be easily produced in large amounts and blended with gasoline or used pure as a "green" fuel. Furthermore, due to the higher oxygen content, ethanol allows a better oxidation of the gasoline and reduces $\mathrm{CO}$ and particulate emissions. Other advantages of ethanol versus gasoline are the higher octane number, broader flammability limits, higher flame speeds, heat of vaporization and compression ratio and a shorter burn time (Balat et al. 2008; Mussatto et al. 2010). The use of bioethanol can also contribute for the reduction of $\mathrm{CO}_{2}$ build-up, while the $\mathrm{CO}_{2}$ content of 
fossil fuels will remain in storage (Sanchez et al. 2008; Gonzalez-Garcia et al. 2009; Chen et al. 2010a; Balat 2011). Moreover, combustion of ethanol results also in lower NOx emissions, being free of sulphur dioxide. However, as disadvantages, ethanol has an energy density lower than gasoline, it is fully miscible in water and its lower vapour pressure makes motor cold start more difficult (Balat et al. 2008; Gonzalez-Garcia et al. 2009; Chen et al. 2010a; Mussatto et al. 2010; Balat 2011). Simultaneously, bioethanol is a building block for the production of several other chemicals, usually petrochemical-based, like acetaldehyde, ethane, ethylene, propylene, butadiene, carbon monoxide or hydrogen (Idriss et al. 2000; Wang et al. 2008; Yu et al. 2009; Lippits et al. 2010; Oakley et al. 2010; Song et al. 2010). Today nearly $95 \%$ of hydrogen is produced from fossil-based materials such as methane and naphtha. Bioethanol as chemical reagent for hydrogen production could be a way to support hydrogen economy from a renewable and clean energy source (Yu et al. 2009; Lippits et al. 2010). Besides, the production of olefins from ethanol has attracted much attention since it valorises bioethanol production under a biorefinery context (Thygesen et al. 2010).

In this context Hardwood Sulphite Spent Liquor (HSSL) is a subproduct of pulp and paper industry that results from the acidic sulphite pulping process in high amounts per day. The main objective of acidic sulphite pulping process is to remove lignin and hemicelluloses from wood and to maintain cellulose integrity as much as possible. In this process, lignin and hemicelluloses are hydrolysed and released in the aqueous phase. HSSL can be a suitable substrate for $2^{\text {nd }}$ generation bioethanol production as well as other biobased products since it is rich in monosaccharides obtained during the acidic sulphite pulping process.

\section{Lignocellulosics: Variety and chemical composition}

\subsection{Lignocellulosic biomass as a renewable resource for energetic, chemicals and materials platform}

Lignocellulosic biomass (LCB) is the most abundant renewable resource on Earth, comprising about $50 \%$ of world biomass. LCB is outside the human food chain and its energetic content exceeds many times world basic energy requirements. These features make it an important option as feedstock, as a relatively inexpensive raw-material, for bioethanol production, and for the development of other bioindustries, to face the international demand for biofuel market. In 2008 it was estimated that $200 \times 10^{9}$ tons of biomass were produced and only $3 \%$ were used in pulp and paper industries (Rutz et al. 2008; Sanchez et al. 2008; Zhang 2008).

The use of LCB as feedstock for bioethanol production results in significant reduction of gas emissions (Sanchez et al. 2008; Brehmer et al. 2009) and in economic profits increase due to low-cost raw-materials (Balat et al. 2008). LCB can be classified based on their origin: wood (softwoods and hardwoods) and shrubs, non-food agricultural crops (kenaf, reed, rapeseed, etc.) and residues (such as olive stones, wheat straw, corncobs, rise husk, sugarcane and winemaking residues, among others), and municipal solid wastes related to thinning, gardening, road maintenance, etc. (Demirbas 2005; Balat et al. 2008; Sanchez et al. 2008). Wastes from pulp and paper industries, as spent liquors, paper broke, fibres from primary sludge, waste newsprint and office paper or recycled paper sludge are another specific group of LCB to consider.

The conversion of LCB to fermentable monomeric sugars is much more difficult than the conversion of starch. Numerous studies on the development of large-scale production of 


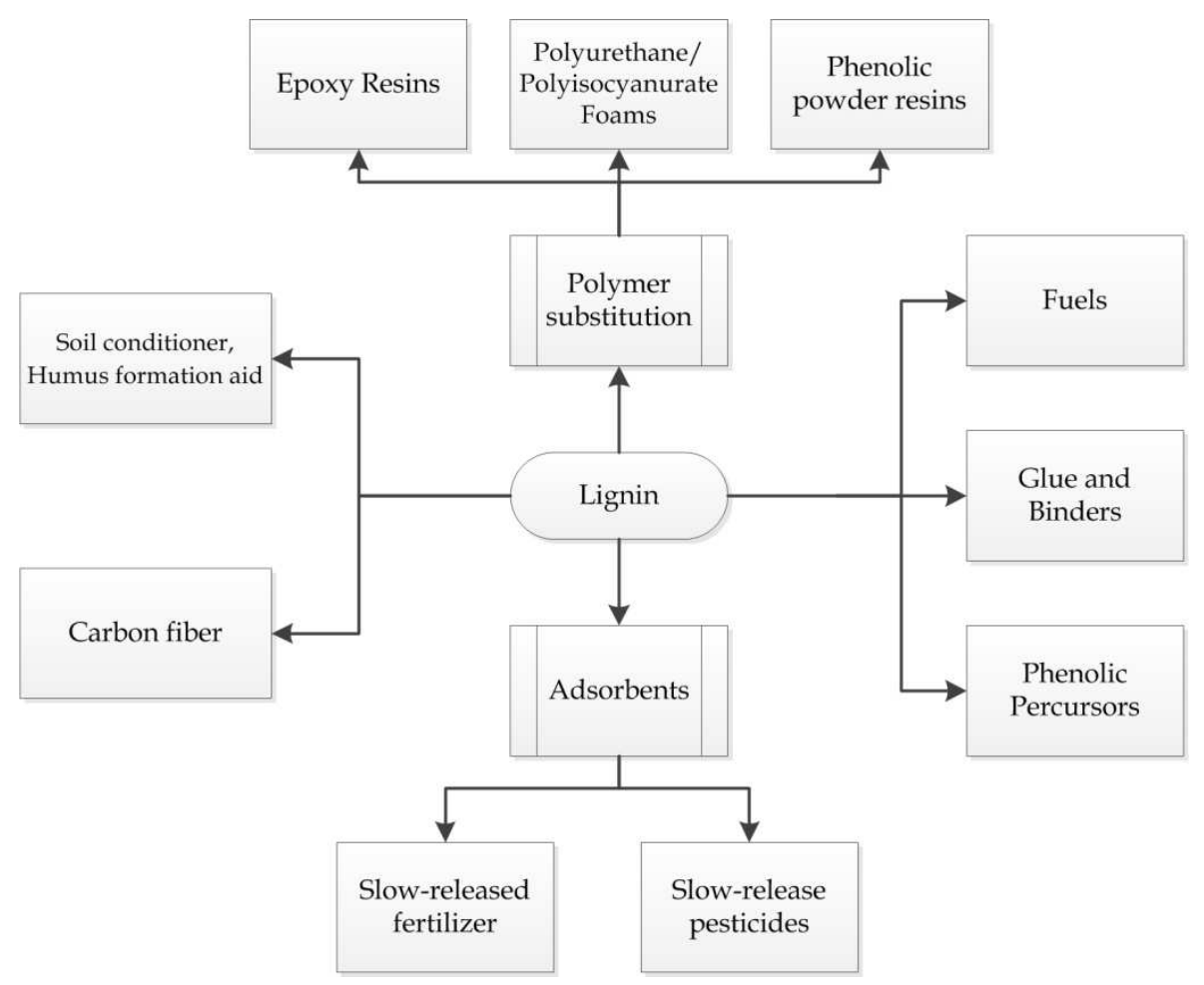

Fig. 1. Lignin potential utilization pathways, adapted from Zhang 2008

ethanol from LCB have been carried out around the world in the last years (Mussatto et al. 2004). The particular inherent structure of LCB is the main limiting factor of its conversion to ethanol. Besides cellulose, with a broad range of applications, lignin and hemicelluloses are also considered promising raw materials for the aforementioned purposes. The brief presentation of potential pathways of lignin and hemicelluloses is depicted in Fig. 1 and Fig. 2 , respectively.

\subsection{Major macromolecular components of lignocellulosic biomass}

The composition of LCB depends on the plant species and consists primarily of cellulose, hemicelluloses and lignin, which are the integral part of cell wall in plant tissues (Fig. 3) (Fengel et al. 2003). Lignin is an amorphous aromatic biopolymer composed of phenyl propane structural units linked by ether and/or carbon-carbon bonds, supplying tissues stiffness, antiseptic, and hydrophobic properties amongst others (Fig. 4). The types of lignin structural units ( $p$-hydroxyphenyl, guaiacyl and syringyl units), their abundance, types and frequency of inter-unit linkages vary significantly from plant to plant (Fengel et al. 2003). Lignin contributes to $15-30 \%$ of plant biomass and is the principal non-hydrolysable residue of LCB.

Cellulose and hemicelluloses are hydrolysable structural polymers of cell wall and the main sources of fermentable sugars (Lawford et al. 1993; Sanchez et al. 2008). Hemicelluloses contribute to $10-40 \%$ of plant material and are essentially heteropolysaccharides constituted 


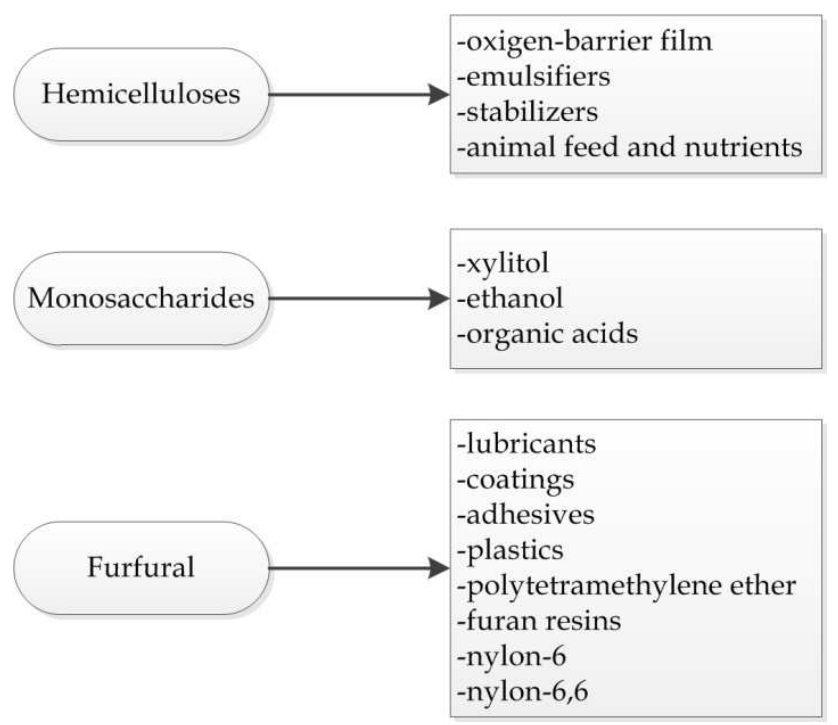

Fig. 2. Hemicelluloses potential utilization pathways, adapted from Zhang 2008

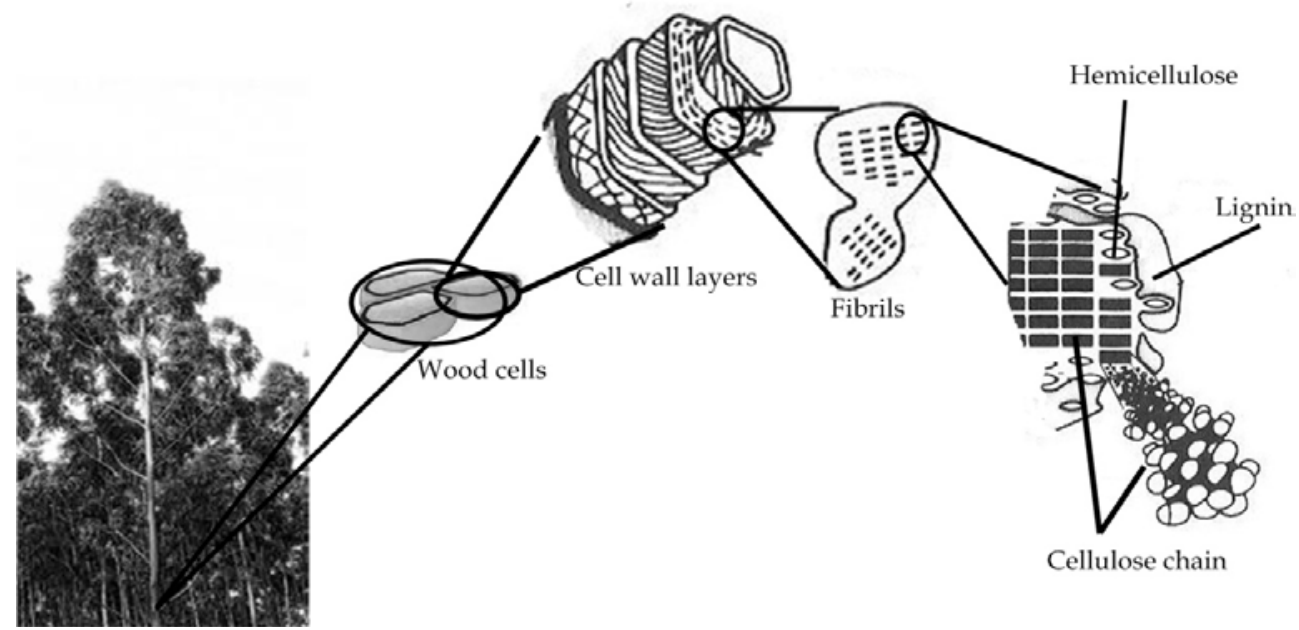

Fig. 3. Representation of wood plant cell wall and its macromolecular components

by pentoses, mainly D-xylose and L-arabinose, and hexoses, mainly D-mannose, D-galactose and D-glucose. These monosaccharides result from pentosans with a main backbone built by pentoses, and hexosans with a main backbone built by hexoses. Hemicelluloses possess an irregular structure and are chemically linked to lignins in the cell wall (Sjöström 1993). The structure and the composition of hemicelluloses vary significantly among plant species. The most abundant hemicelluloses are xylans followed by mannans and galactans (Fig. 5). Hemicelluloses play an important structural role in cell wall regulating the spatial 
distribution of principal macromolecular components (cellulose and lignin) and providing their compatibility.

Cellulose, the most abundant structural polysaccharide (30-50\% abundance in the cell wall), is comprised by repeated $\beta$-D-glucopyranose units linked by $\beta(1 \rightarrow 4)$-glycosidic bonds. In plant cell walls, cellulose chains aggregate into elementary fibrils (EF) which, in turn, are assembled into microfibrils (MF). MF are embedded into a matrix of lignin and hemicelluloses, thus becoming isolated of each other (Fig. 3). Plant cells assembled in different tissues are also separated by a layer enriched in lignin (middle lamella). This structural hierarchy hinders either chemical or enzymatic hydrolysis of cellulose, being the last one particularly difficult. Cellulose, the amorphous-crystalline polymer, is poorly accessible to hydrolysis due to the predominance of crystalline domains.

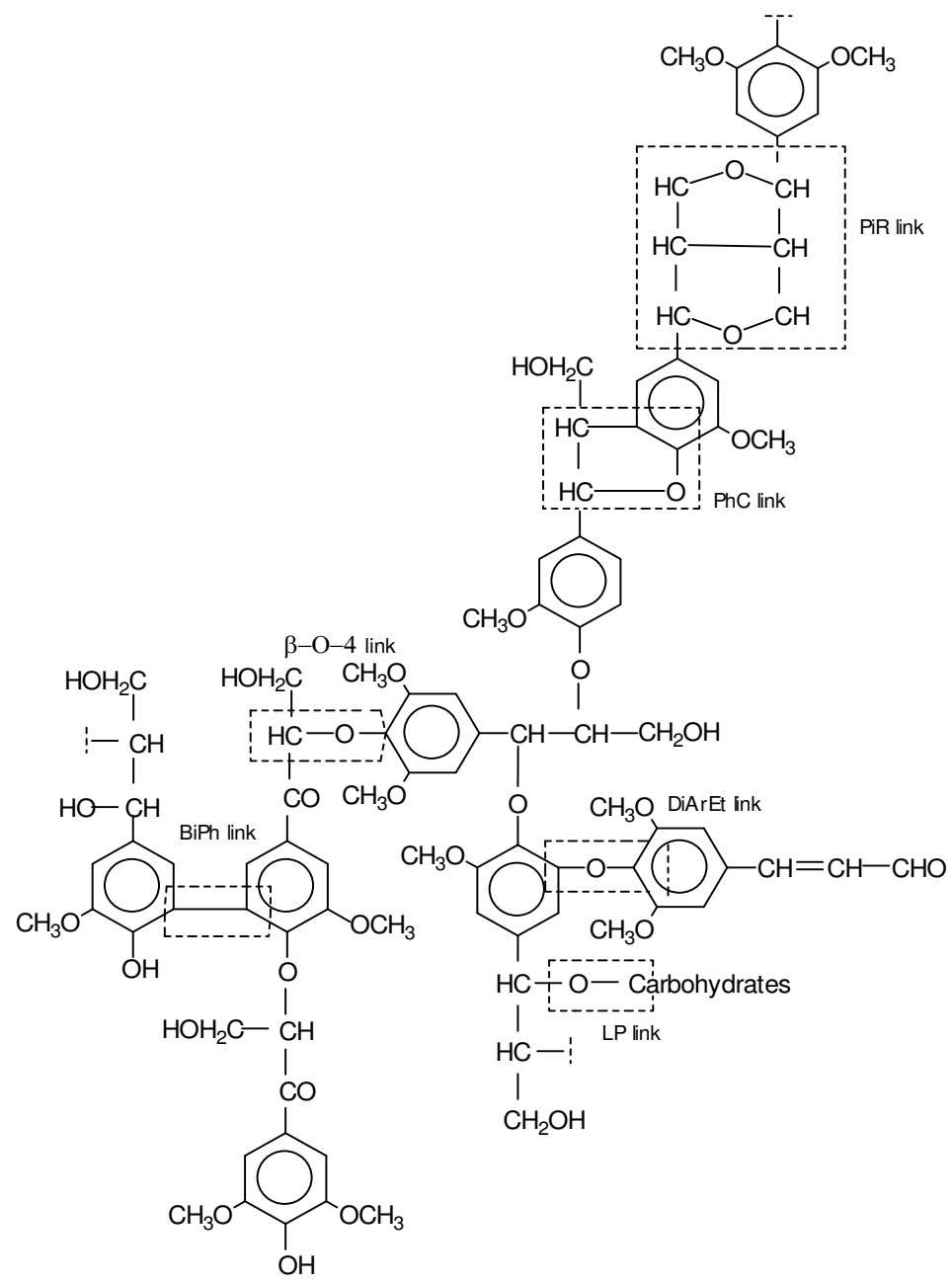

Fig. 4. Schematic representation of lignin (fragment of hardwood lignin) 


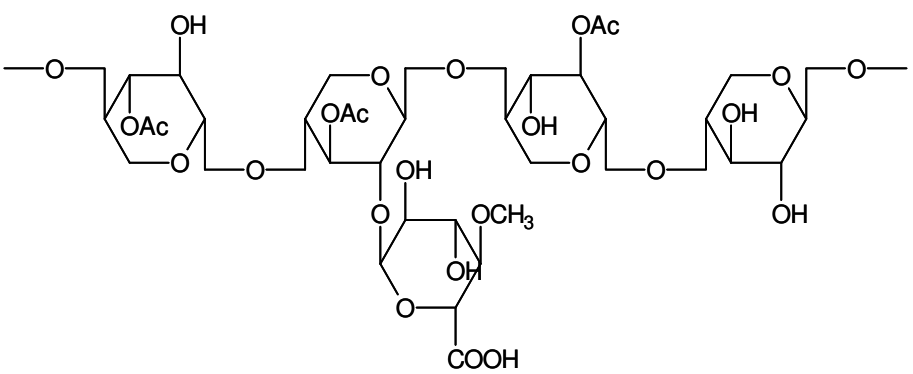

O-acetyl-4-O-methylglucuronoxylan

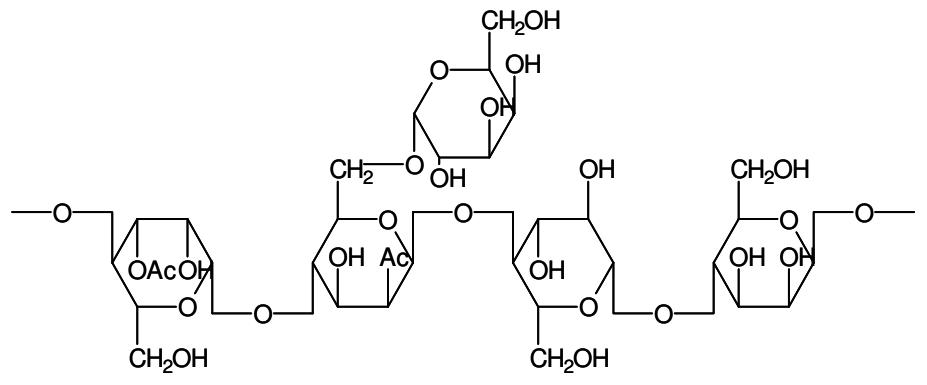

O-acetyl-galactoglucomannan

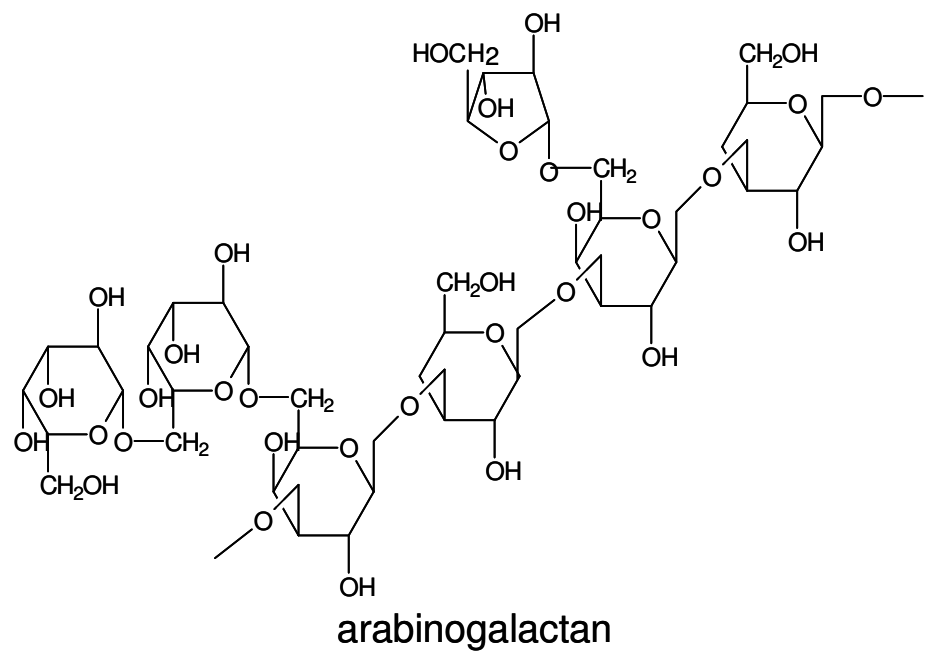

Fig. 5. Schematic representation of major hemicelluloses in lignocellulosics 


\subsection{Hydrolysis of LCB polysaccharides for the ethanol production}

Bioethanol production from LCB includes basically the following steps: (1) hydrolysis of cellulose and hemicelluloses; (2) separation of released sugars from lignin residue (3) fermentation of sugars; (4) recovery and purification of ethanol to meet final specifications. The hydrolysis (saccharification) is one of the most important steps and is technically difficult to perform due to the poor accessibility of cellulose caused by many physical, chemical and structural factors mentioned above. It is an energy consuming task, contributing substantially to the economic costs of the process and is a subject of many research works (Mussatto et al. 2004; Sanchez et al. 2008; Alvira et al. 2010; Sannigrahi et al. 2010). Hydrolysis can be carried out using organic or strong inorganic acids or enzymes as cellulases and hemicellulases. Some characteristics of different conventional and prospective hydrolytic processes are summarised in Table 1.

\begin{tabular}{|c|c|c|c|}
\hline \multirow{2}{*}{ Parameter } & \multicolumn{3}{|c|}{ Hydrolytic processes } \\
\cline { 2 - 4 } & Dilute acid & Concentrated acid & Enzymatic \\
\hline Yield of sugars, \% & ca 50 & $80-90$ & ca 50 \\
\hline Acid consumption & Low & High & High \\
\hline Reactivity of hydrolysis lignin & Low & Low & Pilot scale \\
\hline Technological status & $\begin{array}{c}\text { Commercial in } \\
\text { former USSR }\end{array}$ & Pilot scale & \\
\hline
\end{tabular}

Table 1. Process conditions and properties for different hydrolytic processes

Organic acids, mainly acetic and formic acids, are normally used in the autohydrolysis process and arisen upon hydrothermal treatment of LCB at high temperatures $\left(170-220^{\circ} \mathrm{C}\right)$ as the result of partial degradation of macromolecular components (acetylated xylan/mannan and lignin). These relatively weak organic acids at low concentration are more effective in the hydrolysis of hemicelluloses to a significant extent than of cellulose. Consequently a pre-hydrolysis step is widely used in the production of dissolving pulps by kraft cooking when wood chips are processed prior to pulping by hydrothermal treatment to eliminate significant part of hemicelluloses (Sjöström 1993). The pre-hydrolysis is also a part of pretreatment strategies aiming to hydrolyse selectively the hemicelluloses in LCB to obtain fermentable sugars and/or to improve cellulose accessibility towards hydrolytic enzymes. In this process, the monomeric sugars from hemicelluloses (xylose, galactose, glucose, mannose, and arabinose) and acetic acid are released in the medium (Lawford et al. 1993; Sanchez et al. 2008). Additionally, degradation of lignin/tannins and sugars originate biologically toxic compounds: gallic acid, syringic acid, pyrogallol, vanillic acid, furfural, 5hydroxymethylfurfural, among others (Marques et al. 2009). Significant efforts were done to minimize the production of such highly toxic compounds, as well as acetic acid, for ethanolproducing microorganisms. The pretreatment should improve recovery of sugars from hemicelluloses, facilitate the cellulose hydrolysis step (when the main objective is the complete saccharafication of all polysccharides from LCB), and avoid the formation of inhibitors for subsequent fermentation processes (Mussatto et al. 2004; Alvira et al. 2010; Sannigrahi et al. 2010).

Inorganic acids (mainly $\mathrm{H}_{2} \mathrm{SO}_{4}$ and $\mathrm{HCl}$ ) are effective hydrolysis catalysts and allow complete saccharification of LCB polysaccharides. There are some differences between the use of diluted (1-5\%) and concentrated acids in the hydrolysis step. In the first case the complete saccharification takes place at high temperatures $\left(160-180{ }^{\circ} \mathrm{C}\right)$ and leads to the 
formation of residual hydrolysis lignin (cellolignin) as a massive by-product (Sanchez et al. 2008). Due to drastic reaction conditions, sugars are readily degraded via intramolecular dehydration resulting in furfural from pentoses and 5-hydroxymethylfurfural from hexoses. All of these secondary products have a high inhibitory effect on the metabolism of microorganisms. In order to avoid sugars degradation, these compounds should be continuously removed from the reactor by continuous pumping of "fresh" acidic solution through the biomass bed (percolation hydrolysis). This process is used industrially since $1930^{\text {th }}$ in former USSR and nowadays may be considered outdated due to its poor efficiency: low sugars recovery and production of high amounts of chemically inert hydrolysed lignin. The hydrolysis with concentrated acids $\left(50-70 \%\right.$ of $\mathrm{H}_{2} \mathrm{SO}_{4}$ or $30 \% \mathrm{HCl}$ ) allows for effective saccharification of LCB at moderate temperatures $\left(30-80{ }^{\circ} \mathrm{C}\right)$ for short reaction time with high sugars yield. However, due to the technical difficulties and high consumption of acid, this hydrolysis method is not commercialized yet and is implemented only on pilot scale.

The hydrolysis of polysaccharides by hydrolytic enzymes (cellulases and hemicellulases) is one of the most promising tools for the saccharification of LCB. Hydrolytic enzymes permit highly selective hydrolysis of polysaccharides at relatively low temperatures $\left(30-60{ }^{\circ} \mathrm{C}\right)$, practically without emission of products from sugars degradation. Endo-cellulases break internal bonds to disrupt both the amorphous and the crystalline structures of cellulose, exposing its polysaccharide chains. Exocellulase cleaves two to four units from the ends of the exposed chains produced by endocellulase, while $\beta$-glucosidase hydrolyses the exocellulase product into individual monosaccharides. Since no degradation of glucose occurs, more sugars could be available for a subsequent fermentation, which is the main advantage of this process. However, this process is slower when compared with acidic hydrolysis and hydrolytic enzymes have poor accessibility to polysaccharides of cell wall, especially cellulose. For these reasons this process is time consuming and results in low sugar yields. LCB enzymatic hydrolysis needs a preliminary treatment step to improve the accessibility of enzymatic attack. This preliminary step includes the application of physical methods (mechanical, hydrothermal, etc.) to disintegrate plant tissues and chemical/biochemical treatments to eliminate concomitant biopolymers, mainly lignin and hemicelluloses, hindering the cellulose accessibility. However, the enzymatic efficiency of cellulose conversion still needs to be improved.

The poor efficiency of mild acidic hydrolysis and, particularly, enzymatic biotreatment for direct saccharification of LCB, represents an obstacle for a successful production of secondgeneration biofuels. For this reason, the development of pretreatment techniques to improve cellulose accessibility and saccharification efficiency is a permanent challenge (Sanchez et al. 2008). A general perspective scheme for LCB conversion into ethanol is presented in Figure 6. The first step presumes LCB pretreatment invoked to degrade strong woody biomass matrix and thus blows away the integral tissues. Different lignocellulosic materials have different physic and chemical characteristics and consequently it is necessary to adopt a specific pretreatment suitable for each raw material. The selected pretreatment will have a determinant effect in the subsequent steps. The amount and type of simple sugars released, toxic compounds formed and their concentration, as well as the overall energy demand and wastewater required in the treatments, depend directly on the specific pretreatment applied (Mussatto et al. 2004; Alvira et al. 2010). Several methodologies for biomass pretreatments have been developed during the last decades. They can be classified into biological (using brown, white and soft-rot fungus or their lignolytic and cellulolytic enzymes to degrade lignin and hemicelluloses), physical (mechanical milling and extrusion), chemical (alkali or 
acid pretreatments, ozonolysis, organosolv and pretreatment with ionic liquids) and physicochemical (steam explosion, hydrothermal treatment, ammonia fibre explosion, wet oxidation, microwaves, ultrasound and $\mathrm{CO}_{2}$ explosion) (Balat et al. 2008; Alvira et al. 2010; Sannigrahi et al. 2010). LCB pretreatment leads to partial or major removal of hemicelluloses in the form of mono- or oligosaccharides. Then, cellulose is prepared for the hydrolysis step, if the objective is fermentation of glucose from cellulose, or for further processing to obtain pulps for textile and paper products (Fig. 6). This extra step (dashed) can be catalysed by dilute or concentrated mineral acids or enzymes (cellulases).

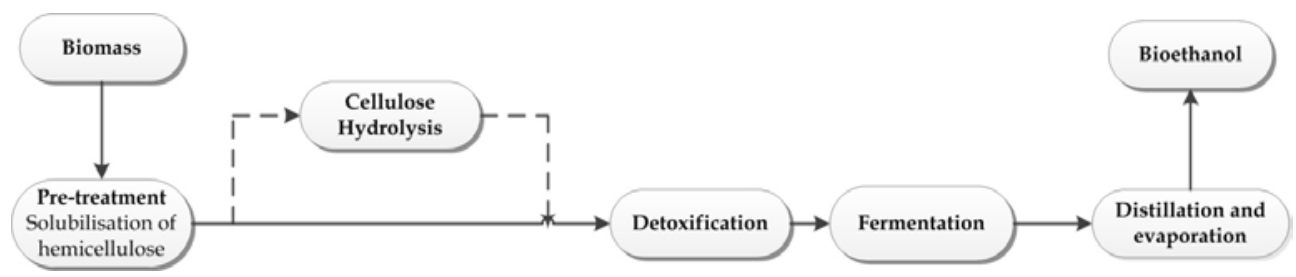

Fig. 6. Schematic steps for production of bioethanol from lignocellulosic biomass

Until now, fuel ethanol from LCB is not yet considered a viable alternative, mainly due to the high complexity involved on this process, compared with the cheaper oil derived fuels. However, in the last years, with the oil crisis, environmental concerns and the increased need for energy and fuels, bioethanol has become a realistic option in the energy market (Cardona et al. 2007; Sanchez et al. 2008). New research has been developed in order to overcome cellulosic to ethanol bioconversion problems and to make this process a costeffective technology, with a process integration that combines different steps into one single unit (Lawford et al. 1993; Cardona et al. 2007). Furthermore, the process integration in other industrial plants, namely large scale industries, can be a good solution for reducing costs of bioethanol production, such as in pulp and paper mill industries, with the advantage of reduced release of subproducts.

\section{HSSL as a source of fermentable sugars}

\subsection{Acidic sulphite wood pulping process and $(\mathrm{H}) \mathrm{SSL}$ composition}

In pulp-and-paper industry the removal of lignin (fibre consolidating material) from wood is carried out during the pulping process to obtain a fibre material (cellulose pulp) suitable for papermaking or as a chemical feedstock. About $10 \%$ of chemical pulps are produced worldwide employing sulphite methods. The acidic sulphite chemical pulping is carried out under acidic conditions ( $\mathrm{pH}$ 1-2) at $135-145{ }^{\circ} \mathrm{C}$ for $6-12 \mathrm{~h}$ in batch digesters using $\mathrm{SO}_{2} / \mathrm{MeHSO}_{3}$ (Me - pulping base) aqueous solution (Sjöström 1993). During sulphite pulping process, lignin and part of hemicelluloses (about $50 \%$ based on wood) are dissolved in sulphite spent liquors (SSLs) composed by monomeric sugars already in the fermentable form. Roughly 1 ton of solid waste is dissolved in the spent liquor (SSL 11-14\% solids) per ton of pulp produced. SSLs are produced in large amounts, about 90 billion litres annually worldwide (Lawford 1993). SSL is usually burned, for chemical and energy recovery after its concentration by evaporation (Fig. 7). The utilization of SSL is considered for a long time to produce value-added products fitting well to the biorefinery concept (Lawford et al. 1993; Marques et al. 2009). 


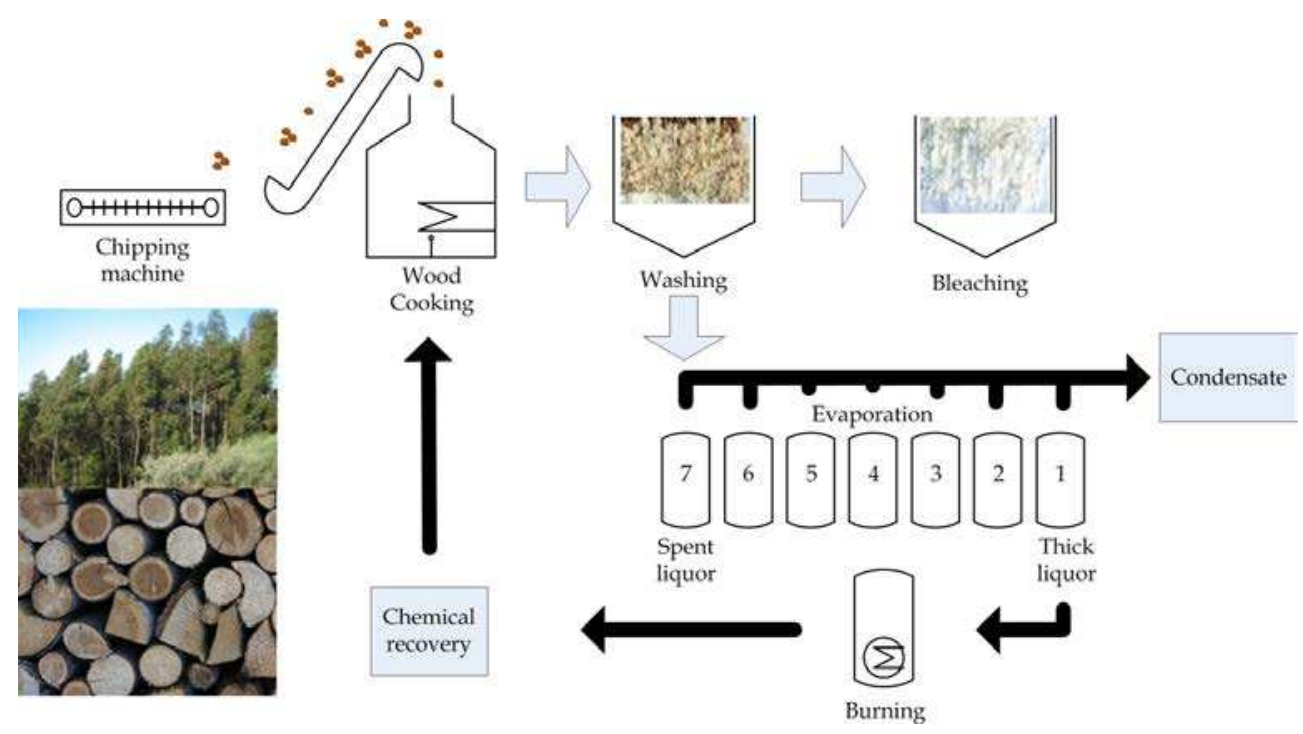

Fig. 7. Representation of acidic sulphite wood pulping process with Spent Sulphite Liquor release

For this reason, the use of raw materials like SSL is advantageous over other agro-forestry wastes, since the more complex lignocellulosic components were previously hydrolysed, releasing most of the sugars as monosaccharides. Consequently this process is already costeffective for pulp production, improving the $2^{\text {nd }}$ generation bioethanol process economy from SSL (Lawford et al. 1993; Helle et al. 2008; Marques et al. 2009; Xavier et al. 2010). However, besides monosacharides, SSL contains several fermentation inhibitors that require a preliminary detoxification step (Lawford et al. 1993; Xavier et al. 2010).

The major organic components of SSLs are, lignosulphonates, and sugars, and their composition varies notably among softwoods and hardwoods (Table 2). Softwood sulphite spent liquor (SSSL) from coniferous, yields a high proportion of hexose sugars content (about $76 \%$ ), mainly mannose and glucose, while HSSL, from hardwood Eucalyptus globulus, produces a liquor with high content of pentose sugars (xylose about 70\%). Hexoses bioprocessing is well studied and already implemented in different processes, while pentoses are difficult to use as feedstock for industrial bioprocesses, because pentoses are not fermented by the yeasts currently used on ethanol production, namely Saccharomyces cerevisiae. Therefore, while the use of SSSL has been studied since 1907, when SSSL was used in Sweden for bioethanol production and also during the World War II, for yeast production as a source of protein and vitamins, the HSSL bioprocessing only recently become investigated (Lawford et al. 1993; Helle et al. 2008; Marques et al. 2009; Xavier et al. 2010). Pichia stipitis, recently reclassified as Scheffersomyces stipitis (Kurtzman and Suzuki, 2010), is the most studied yeast capable to convert pentoses to ethanol. However, this yeast is highly sensitive to HSSL inhibitors, namely formic and acetic acids, furfural, levulinic acid and phenolics. For this reason, HSSL needs a special pretreatment for inhibitors removal, which is another technical issue to consider (Helle et al. 2008; Xavier et al. 2010). 


\begin{tabular}{|l|c|c|c|}
\hline Component & $\begin{array}{c}\text { Spruce } \\
52 \% \text { yield }\end{array}$ & $\begin{array}{c}\text { Birch }^{1} \\
49 \% \text { yield }\end{array}$ & $\begin{array}{c}\text { Eucalyptus }^{2} \\
52 \% \text { yield }\end{array}$ \\
\hline Lignosulfonates & 480 & 370 & 360 \\
\hline Carbohydrates & 280 & 375 & 200 \\
Xylose & 60 & 340 & 135 \\
Mannose & 120 & 10 & 5 \\
Arabinose & 10 & 10 & 5 \\
Galactose & 50 & 10 & 30 \\
Glucose & 40 & 5 & 20 \\
\hline Acetic acid & 40 & 40 & 50 \\
\hline Extractives & 40 & 60 & 20 \\
\hline
\end{tabular}

1 (Sjöström 1993)

2 (Marques et al. 2009)

Table 2. Chemical composition of Spent Sulphite Liquors of Spruce, Birch and Eucalyptus wood (approximate values given in kilograms per ton of pulp)

\subsection{Fermentation inhibitors and their removal}

As mentioned before, during the conversion of LCB into monomeric sugars, other type of products are formed and some of them can be strong inhibitors in fermentation bioprocesses. When compared to the fermentation of pure sugars, LCB hydrolysates present slower kinetics with a lower ethanol yield and productivity and in some cases a complete inhibition of growth and ethanol production can be observed. The variety and concentration of toxic compounds in feedstocks depend on both, the raw material and the pretreatment conditions applied for polysaccharides hydrolysis. The maximum concentration allowed for each inhibitor, without losing fermentation efficiency, depends on several factors: the origin of toxic compound, the inhibition mechanism, the microbial strain used and its physiological state, and also the fermentative process technology, the dissolved oxygen concentration in the medium and the $\mathrm{pH}$ (Mussatto et al. 2004).

Selection of a detoxification methodology for a specific feedstock is mandatory for attaining good results in $2^{\text {nd }}$ generation bioethanol production. The identification of the main and relevant inhibitors present in the feedstocks is crucial in order to choose a specific, efficient and low-cost detoxification methodology. Besides, this knowledge can helps to establish the best conditions in hydrolysis pretreatment in order to minimize the inhibitors formation.

Fermentation inhibitors are conventionally classified in four groups according to their origin in lignocellulosics and hydrolysis processing: sugar degradation products, lignin degradation products, compounds derived from extractives and heavy metal ions (Parajó et al. 1998; Mussatto et al. 2004). Sugar degradation products are formed during hydrolysis and the main compounds produced are furfural from pentoses and 5-hydroxymethylfurfural (HMF) from hexoses as mentioned above. Furfural can inhibit cell growth, affecting the specific growth rate and cell-mass yield (Palmqvist et al. 2000b). However, it was noticed that some bioethanol-producing microorganisms like Pichia stipitis are not affected by furfural in low concentrations up to 0.5 g.L.-1 (Mussatto et al. 2004). Moreover it could have a positive effect on cell growth. Nigam (2001) referred that ethanol yield and productivity were not affected by $0.27 \mathrm{~g} . \mathrm{L}^{-1}$ of furfural. However concentrations above $1.5 \mathrm{~g} . \mathrm{L}^{-1}$ interfered in respiration and inhibited cell growth almost completely, decreasing ethanol yield in $90 \%$ 
and productivity in $85 \%$ (Nigam 2001b). HMF has an inhibitory effect similar to that of furfural, but at a lower extension. Usually HMF is present in lower concentrations than furfural, due to its high reactivity and also due to the experimental conditions in the hydrolysis process that degrades lower amounts of hexoses. It was reported that HMF increases the lag phase extension and decreases cell growth (Delgenes et al. 1996; Palmqvist et al. 2000b). Mussatto et al. (2004) reported that a synergistic effect occurs when these compounds are combined with several other compounds formed during lignin degradation. Different compounds, aromatic, polyaromatic, phenolic, and aldehydic can be released from lignin during hydrolysis of LCB materials, and they are considered more toxic to microorganisms than furfural and HMF, even in low concentrations. Phenolic compounds are the most toxic products for microorganisms present in lignocellulosic hydrolyzates. They promote a loss of integrity in biological membranes, thus, affecting their ability as selective barriers and as enzyme matrices and decreasing cell growth and sugar assimilation (Parajó et al. 1998; Palmqvist et al. 2000b). Syringaldehyde and vanillic acid affect cell growth (Mussatto et al. 2004; Cortez et al. 2010) and the ethanolic fermentative metabolism of several microorganisms, like $P$. stipitis (Delgenes et al. 1996). In SSL, these compounds are normally present in the sulphonated form, due to the cooking process (Marques et al. 2009).

Extractives (acidic resins, taninic, and terpene acids) and also acetic acid derived from acetyl groups present in the hemicellulose are released during the hydrolytic processes. In terms of toxicity, the extractives are considered less toxic to microbial growth, than lignin derivatives or acetic acid (Mussatto et al. 2004). Gallic acid and pyrogallol are low molecular weight phenolic compounds normally formed from hydrolysable tannins (Marques et al. 2009) and some authors have shown anti-fungal properties of these phenolics (Dix 1979; Panizzi et al. 2002; Upadhyay et al. 2010). Acetic acid is also known as antimicrobial compound and the mechanism of inhibition is well-understood. At low $\mathrm{pH}$, in the undissociated form, it can diffuse across the cell membrane, promoting the decrease of the cytoplasmatic cell activity and even causing cell death (Lawford et al. 1998; Mussatto et al. 2004). It has been reported that acetic acid inhibition degree depends not only on its concentration, but also on oxygen concentration and on $\mathrm{pH}$ of fermentation medium (Vanzyl et al. 1991). Another type of inhibitors are heavy metal ions, namely iron, chromium, nickel and copper, which result from reactors corrosion during the acidic hydrolysis pretreatment. Their toxicity acts at metabolic pathways level, by inhibiting enzyme activity (Mussatto et al. 2004).

As previously mentioned, a detoxification step is required before the hydrolysates undergo fermentation. Therefore, after identification of the toxic compounds, the choice of the best hydrolysate detoxification method is crucial for an effective and economical feasible detoxification methodology, in order to improve the fermentative process (Mussatto et al. 2004; Sanchez et al. 2008). Three different approaches have been described to decrease the concentration of inhibitors: (1) prevention of formation of inhibitors during the pretreatment step as mentioned before; (2) detoxification of the raw-material before fermentation; (3) development of microorganisms able to resist to inhibition.

Xavier and co-workers (2010) reported HSSL containing nearly 25 g.L-1 of xylose to P. stipitis for bioethanol production. Four increasing concentrations of HSSL were accessed to evaluate its toxicity. The results showed that increasing HSSL content in the fermentation medium decreased dramatically the maximum cell growth rate $\left(\mu_{\max }\right)$, ethanol yield $\left(\mathrm{Y}_{\mathrm{p} / \mathrm{s}}\right)$ and productivity $\left(\mathrm{qp}_{\mathrm{m}}\right)$ attained. It was reported that HSSL content higher than $40 \%(\mathrm{v} / \mathrm{v})$ was critical for bioethanol production (Table 3). Acetic acid has been appointed as the main inhibitor of P. stipitis and other microorganisms (Schneider 1996; Lawford et al. 1998; Nigam 


\begin{tabular}{|c|c|c|c|c|}
\hline HSSL content $(\%)$ & $\mu_{\max }\left(\mathrm{h}^{-1}\right)$ & $\mathrm{qp}_{\mathrm{m}}\left(\mathrm{g} \cdot \mathrm{L}^{-1} \cdot \mathrm{h}^{-1}\right)$ & $\mathrm{Y}_{\mathrm{p} / \mathrm{s}}\left(\mathrm{g}_{\left.\mathrm{e} . \mathrm{g}_{\mathrm{s}}{ }^{-1}\right)}\right.$ & Acetic acid $\left(\mathrm{g} \cdot \mathrm{L}^{-1}\right)$ \\
\hline 0 & 0.37 & 0.77 & 0.37 & 0 \\
\hline 20 & 0.32 & 0.40 & 0.30 & 1.6 \\
\hline 40 & 0.12 & 0.10 & 0.23 & 3.3 \\
\hline 60 & 0 & 0 & 0 & 4.9 \\
\hline
\end{tabular}

Table 3. Results of bioethanol production by P. stipitis at different HSSL contents (Xavier et al. 2010)

2001a). After the removal of acetic acid, ethanol fermentations were still unsuccessful, meaning that other compounds present had a toxic effect (Xavier et al. 2010).

Several biological, physical and chemical detoxification methods were developed in order to reduce inhibitor concentrations. The efficiency of detoxification methodology depends on chemical composition of the hydrolysate, as well as on microorganism chosen for bioethanol production (Mussatto et al. 2004; Helle et al. 2008; Sanchez et al. 2008). For this reason, the detoxification methods cannot be directly compared since mechanisms of inhibition and degree of toxicity removal are completely different (Palmqvist et al. 2000a).

Evaporation with vapour and vacuum evaporation are physical detoxification methods, in order to reduce the concentration of volatile compounds present in the hydrolysates, such as acetic acid, furfural and formaldehyde, and at the same time, to increase sugars concentrations. However, these methods also increase the non-volatile toxic compounds content, such as extractives and lignin derivatives. A balance between these two effects should be achieved or, consequently, the degree of fermentation inhibition will increase. Furthermore, the energy required for these processes should be properly considered to attain a potential economical gain (Lawford et al. 1993; Mussatto et al. 2004). As mentioned above, in the particular case of HSSL, evaporation is already implemented in the pulp production process for liquor concentration, to prepare it to burn for energy and chemical recovery. This is an advantage for HSSL bioconversion, and it is possible to optimise the evaporation stage, in order to get a good balance between volatile and non-volatile toxic compounds and sugar concentration for the fermentation process. Additionally, the condensate obtained in this step is rich in furfural and acetic acid, that can be easily extracted and purified for selling purposes as added-value products (Evtuguin et al. 2010).

Alkali treatment, in particular overliming, is the most common detoxification method and is considered one of the best technologies. This method consists on the addition of lime $\left(\mathrm{Ca}(\mathrm{OH})_{2}\right)$, or other alkali compound such as sodium or potassium hydroxide, until $\mathrm{pH} 9-10$ promoting the precipitation of toxic compounds. Acetic acid, furfural, HMF, soluble lignin and phenolic compounds are mostly removed with this methodology, increasing the fermentability of hydrolysates. Several authors obtained the best results with alkali treatment using calcium hydroxide (Lawford et al. 1993; Martinez et al. 2001; Helle et al. 2008; Sanchez et al. 2008). Martinez et al. (2001) reported for sugarcane bagasse hydrolysate at 60 ${ }^{\circ} \mathrm{C}$ that the addition of $\mathrm{Ca}(\mathrm{OH})_{2}$ to adjust the $\mathrm{pH}$ to 9.0 , promoted the precipitation of furanic and phenolic compounds. The obtained results showed a removal of nearly $51 \%$ and $41 \%$ respectively, of furans and phenolics with only $8.7 \%$ of sugars loss. Lawford et al. (1993) also used $\mathrm{Ca}(\mathrm{OH})_{2}$ for HSSL treatment at $\mathrm{pH} \mathrm{10}$, followed by neutralisation to $\mathrm{pH} 7$ with $1 \mathrm{~N}$ of $\mathrm{H}_{2} \mathrm{SO}_{4}$. This methodology resulted in the improvement of the volumetric productivity and conversion efficiency, $92 \%$, of bioethanol production by a recombinant strain of Escherichia coli. 
Toxic compounds can also be removed by adsorption. Several authors have studied the capacity of removal of toxic compounds using different materials as adsorbents such as, activated charcoal (Dominguez et al. 1996; Lee et al. 1999; Mussatto et al. 2001; Canilha et al. 2004) and ion-exchange resins (Vanzyl et al. 1991; Larsson et al. 1999; Lee et al. 1999; Nilvebrant et al. 2001; Xavier et al. 2010). In particular, a specific strategy of adsorption on ion-exchange resins was employed by Xavier et al. (2010) to toxic compounds removal from HSSL for subsequent sugar purification and then ethanol fermentation with P. stipitis (Fig. 8).

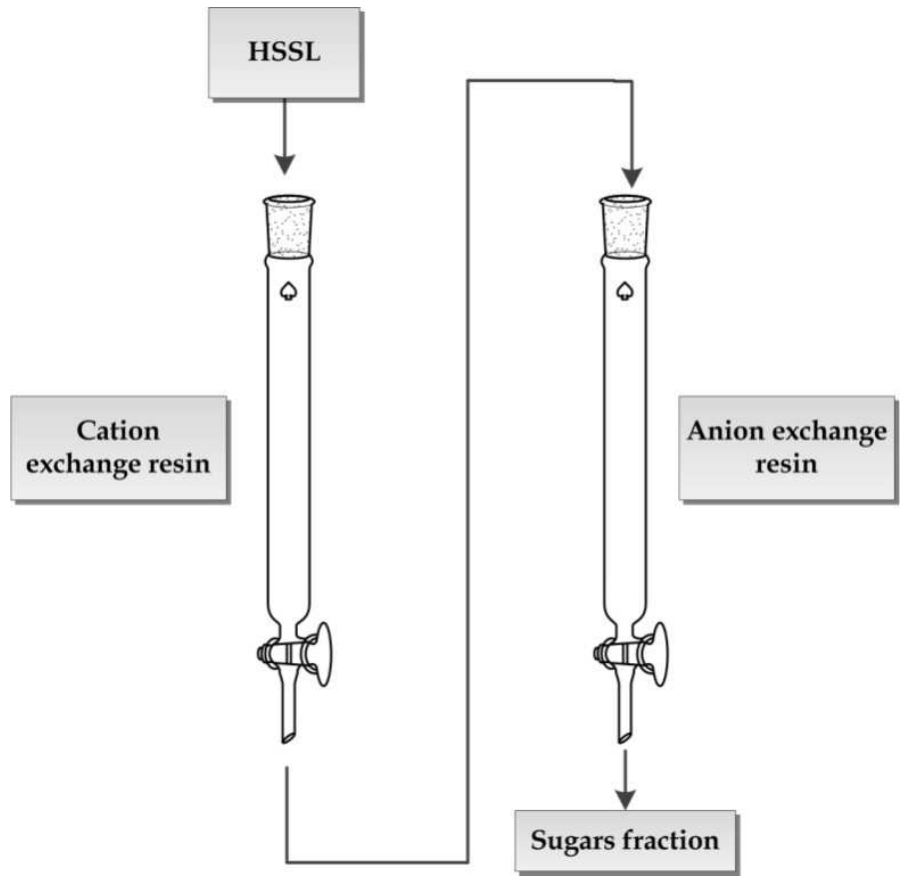

Fig. 8. Scheme of HSSL detoxification by adsorption of inhibitors using ion-exchange resins

In order to remove the cations added during pulping processing, namely $\mathrm{Mg}^{2+}, \mathrm{HSSL}$ was initially treated with a cation-exchange resin column. Then free carboxylic acids and polyphenols, including lignosulphonates, were separated from sugars with an anionexchange resin in the second column. This process provided a transparent solution (sugars faction) containing essentially neutral monomeric sugars with traces of neutral polyphenolics (Table 4). However, this separation process released the sugars with some dilution and a concentration step was required for fermentation. This procedure led to excellent results of ethanol production by $P$. stipitis: high fermentation efficiency, $96 \%$, productivity, $1.22 \mathrm{~g} \cdot \mathrm{L}^{-1} \cdot \mathrm{h}^{-1}$, and yield, $0.49 \mathrm{~g}$ of ethanol / $\mathrm{g}$ of sugar.

Biological methods for detoxification of hydrolysates involve the use of specific enzymes or microorganisms that can degrade or consume the toxic compounds present in the hydrolysates. Jönsson et al. (1998) reported an increasing glucose consumption and ethanol productivity when wood hydrolysates were detoxified with laccase and peroxidase enzymes from Trametes versicolor, a white-rot fungus. These oxidative enzymes have the capability to degrade acid and phenolic compounds (Jonsson et al. 1998). The use of 


\begin{tabular}{|c|c|}
\hline Compound & Concentration $\left(\mathrm{g} . \mathrm{L}^{-1}\right)$ \\
\hline Lignosulphonates & traces \\
\hline Acetic acid & n.d. $^{\mathrm{a}}$ \\
\hline $\mathrm{pH}$ & $5.4 \pm 0.1$ \\
\hline Xylose & $5.7 \pm 0.3$ \\
\hline Glucose & $0.5 \pm 0.2$ \\
\hline
\end{tabular}

anot detected

Table 4. Chemical composition of sugars fraction after ion-exchange detoxification

microorganisms was also proposed to remove inhibitors from HSSL. Xavier and co-workers (2010) presented the first approach for HSSL biological detoxification, specifically for acetic acid removal. Four yeasts commonly used for acetic acid removal from wine were chosen, Candida tropicalis, Candida utilis, S. cerevisiae and Pichia anomala, and results are presented in Table 5.

\begin{tabular}{|c|c|c|}
\hline Yeast & $\mu_{0}\left(\mathrm{~h}^{-1}\right)$ & $\begin{array}{c}\text { Time of complete } \\
\text { consumption of acetic acid (h) }\end{array}$ \\
\hline Saccharomyces cerevisiae & $0.15 \pm 0.02$ & 20 \\
\hline Candida tropicalis & $0.14 \pm 0.03$ & 70 \\
\hline Candida utilis & $0.16 \pm 0.05$ & 220 \\
\hline Pichia anomala & $0.22 \pm 0.03$ & 72 \\
\hline
\end{tabular}

Table 5. Results of biological deacidification of HSSL (Xavier et al. 2010)

According to these results, S. cerevisiae was selected for biological deacidification of HSSL. Sequential strategy of deacidification by S. cerevisiae and fermentation by P. stipitis on $60 \%$ of HSSL was carried out. Despite the acetic acid consumption by $S$. cerevisiae, xylose fermentation by $P$. stipitis produced only cell biomass, and no ethanol was detected in the medium. These results clearly showed the presence of other toxic compounds from HSSL, eventually phenolic compounds, probably inhibiting the sugars conversion to ethanol by $P$. stipitis (Xavier et al. 2010).

A different approach for performing biological detoxification of HSSL, with better results, was made in the same research group, using the Paecilomyces variotti filamentous fungus. This fungus can be found in air and soils of tropical countries, and has been studied for single cell protein (SCP) production, another important added-value product, normally used in animal feeding (Nigam 1999). Besides, P. variotti presents a good performance to grow in residues like HSSL and consumes substrates, including phenolic compounds, as carbon source. Pereira et al. (2011) showed for the first time the possibility of using this fungus to detoxify HSSL hydrolysates for subsequent ethanol fermentation. The biological treatment with $P$. variotti yielded HSSL with very low levels of acetic acid. Moreover, toxic compounds like gallic acid, pyrogalol and other low molecular phenolics were completely consumed and metabolized by $P$. variotti, indicating that this detoxification method can be suitable for treating HSSL into a proper feedstock for further bioprocessing. A successful fermentation of this detoxified HSSL by $P$. stipitis was performed, attaining an ethanol yield of 0.24 $\mathrm{g}_{\text {ethanol. }} \mathrm{g}_{\text {sugars }}{ }^{-1}$. However, more research is required in order to improve the ethanol fermentation yields and productivities (Pereira et al. 2011). 
Comparing the four different detoxification methodologies described, ion-exchange resins provided the best results on subsequent bioethanol fermentation (Table 6). High percentages of different toxic compounds from the hydrolysate were removed and provided the highest ethanol yield $\left(0.49 \mathrm{~g} \cdot \mathrm{g}^{-1}\right)$ and volumetric productivity $\left(1.22 \mathrm{~g} . \mathrm{L}^{-1} \cdot \mathrm{h}^{-1}\right)$. However, ion-exchange resins are expensive and difficult to implement and operate in large scale industries. $P$. variotti treatment, despite the fact of having promoted low ethanol fermentation yields in preliminary results (Table 6), appeared to be a very promising detoxification method. Furthermore the biomass of $P$. variotti can be used as SCP for animal feeding, increasing the economic potential of the process. More research work is being developed to combine this coupled strategy of biological detoxification of HSSL with simultaneous SCP production (Pereira et al. 2011). Other approaches for detoxification of hydrolysates were proposed and different methods can be used sequentially to improve their own capacity (Mussatto et al. 2004).

\begin{tabular}{|c|c|c|c|c|c|}
\hline Treatment & $\begin{array}{l}\text { Ethanol } \\
\left(\text { g. } L^{-1}\right)\end{array}$ & $\begin{array}{c}\mathrm{Y}_{\mathrm{p} / \mathrm{s}} \\
\left(\mathrm{g}_{\text {et }} \cdot \mathrm{g}_{\mathrm{s}^{-1}}\right)\end{array}$ & $\begin{array}{c}\text { Conversion } \\
\text { Efficiency } \\
(\%)\end{array}$ & $\begin{array}{l}\text { Strain and } \\
\text { feedstock }\end{array}$ & Reference \\
\hline $\begin{array}{c}\text { Ion-exchanges } \\
\text { Resins } \\
\end{array}$ & 8.10 & 0.49 & 96 & P. stipitis/HSSL & $\begin{array}{c}\text { (Xavier et al. } \\
2010)\end{array}$ \\
\hline $\begin{array}{c}\text { Evaporation + } \\
\text { alkaline } \\
\text { treatment }\end{array}$ & 9.7 & 0.30 & 59 & P. stipitis/HSSL & (Nigam 2001a) \\
\hline P. variotti & 2.36 & 0.24 & 47 & P. stipitis/HSSL & $\begin{array}{l}\text { (Pereira et al. } \\
\text { 2011) }\end{array}$ \\
\hline $\begin{array}{c}\text { Ion-exchanges } \\
\text { Resins }\end{array}$ & n.a. & 0.45 & 88 & $\begin{array}{c}\text { S. cerevisiae/ } \\
\text { Spruce } \\
\text { hydrolysate }\end{array}$ & $\begin{array}{c}\text { (Nilvebrant et } \\
\text { al. 2001) }\end{array}$ \\
\hline $\begin{array}{l}\text { Alkaline } \\
\text { treatment }\end{array}$ & 10.0 & 0.40 & 78 & Escherichia coli & $\begin{array}{c}\text { (Lawford et al. } \\
1993 \text { ) }\end{array}$ \\
\hline $\begin{array}{l}\text { Alkaline } \\
\text { treatment }\end{array}$ & 12.2 & 0.25 & 49 & P. stipitis & $\begin{array}{l}\text { (Vanzyl et al. } \\
\text { 1988) }\end{array}$ \\
\hline
\end{tabular}

Table 6. Results of bioethanol production for different detoxification methodologies

\subsection{Microorganisms and their metabolism}

The extension of substrate utilisation is critical to determine the economic viability of ethanol production from LCB. This presumes a complete conversion of sugars presented in feedstocks to ethanol under industrial conditions. Under an industrial context, the microorganism chosen should meet some requirements, which are discussed in relation to four benchmarks: (1) Process water economy; (2) Inhibitor tolerance; (3) Ethanol yield; (4) Specific ethanol productivity. Several species of bacteria, yeast and filamentous fungi naturally ferment sugars to ethanol. Each microorganism has its advantages and disadvantages, some can use only hexoses for producing ethanol and others can use both, hexoses and pentoses, but many times with low ethanol yields (Hahn-Hagerdal et al. 2007). The mixture of sugars obtained after LCB hydrolysis, besides glucose, also contains other sugars e.g. xylose, mannose, galactose, arabinose and also some oligosaccharides. Therefore, in the fermentation process, microorganisms ferment these sugars into bioethanol according 
to reactions presented below. The calculation of the theoretical maximum yield should follow equation 1 for pentoses or equation 2 for hexoses:

$$
\begin{gathered}
3 \mathrm{C}_{5} \mathrm{H}_{10} \mathrm{O}_{5} \rightarrow 5 \mathrm{C}_{2} \mathrm{H}_{5} \mathrm{OH}+5 \mathrm{CO}_{2} \\
\mathrm{C}_{6} \mathrm{H}_{12} \mathrm{O}_{6} \rightarrow 2 \mathrm{C}_{2} \mathrm{H}_{5} \mathrm{OH}+2 \mathrm{CO}_{2}
\end{gathered}
$$

According to these equations, the theoretical maximum yield is $0.51 \mathrm{~g}$ bioethanol and $0.49 \mathrm{~g}$ carbon dioxide per $\mathrm{g}$ of xylose and glucose.

In order to obtain an economically feasible conversion process of any biomass, it is imperative that the microorganisms chosen should be able to convert efficiently all the sugars present into the desired end product, in this case bioethanol (Chu et al. 2007; HahnHagerdal et al. 2007; Matsushika et al. 2009). The ideal yeast for bioethanol production from LCB should consume the sugars present and provide high production yields as well as specific productivities. Moreover it should not suffer any inhibition from the other components of the raw material (Hahn-Hagerdal et al. 2007).

One of the most effective and well-known ethanol producing microorganisms from hexose sugars is the yeast $S$. cerevisiae. This yeast is successfully employed at industrial scale, allowing for high ethanol productivity, since it bears high tolerance to ethanol and to inhibitors normally present in lignocellulosic residues. However, this yeast is unable to ferment xylose to ethanol efficiently, though it can only ferment its isomer, xylulose (Jeppsson et al. 2006; Chu et al. 2007; Hahn-Hagerdal et al. 2007; Matsushika et al. 2009). Some yeasts were reported to be efficient in xylose conversion to ethanol, such as, P. stipitis, Candida shehatae and Pachysolen tannophilus (Huang et al. 2009). Among them, P. stipitis exhibits the best potential for industrial application due to the high ethanol yield obtained (Huang et al. 2009). Nevertheless, this yeast is sensitive to organic acids, including acetic acid, which are present in lignocellulosic residues. These compounds inhibit both cell growth and the bioethanol production (Bajwa et al. 2009; Huang et al. 2009). Although, wild type S. cerevisiae cannot ferment xylose to ethanol, several genetic engineered strains have been already developed (Hahn-Hagerdal et al. 2007; Mussatto et al. 2010). Other yeasts, like $P$. stipitis, can naturally utilize both types of sugars with high yields and its use for producing $2^{\text {nd }}$ generation bioethanol from HSSL is being developed (Xavier et al. 2010). Hence, it is important to improve the yeast strain with the most promising characteristics in order to optimize ethanol production from LCB hydrolysates through genetic engineering and/or strain adaptation (Chu et al. 2007; Hahn-Hagerdal et al. 2007; Matsushika et al. 2009). Table 7 summarizes the fermentation performance of several yeasts in different media.

Among bacteria, the most promising for industrial implementation are Escherichia coli, Klebsiella oxytoca and Zymomonas mobilis. Z. mobilis is the bacteria which has the lowest energy efficiency resulting in a higher ethanol yield (up to $97 \%$ of theoretical maximum). However, this bacterium is only able to ferment glucose, fructose and sucrose to ethanol. Another problem appears when the medium has sucrose, due to the formation of the polysaccharide levan (made up of fructose), which increases the viscosity of fermentation broth, and of sorbitol, a product of fructose reduction that decreases the efficiency of the conversion of sucrose into ethanol (Lee et al. 2000). K. oxytoca, an enteric bacterium, found in paper, pulp streams and different sources of wood, is able to grow at low $\mathrm{pH}$ (minimum 5.0) and temperatures up to $35^{\circ} \mathrm{C}$. This bacterium is able to grow either on hexoses or pentoses, as well as on cellobiose and cellotriose (Lee et al. 2000; Cardona et al. 2007; Chen et al. 2010b). 


\begin{tabular}{|c|c|c|c|c|c|c|c|c|c|c|c|c|}
\hline 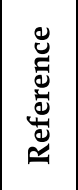 & 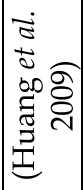 & 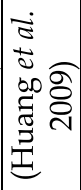 & 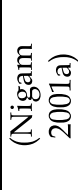 & 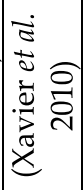 & 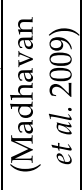 & 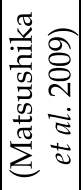 & 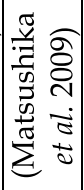 & 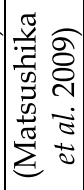 & 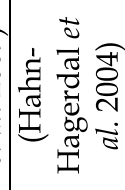 & 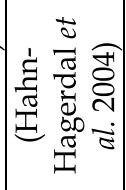 & 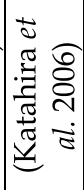 & 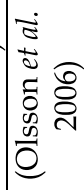 \\
\hline 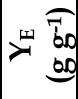 & ळे & 胥 & @ి & 䎹 & 岗 & ח. & חִ & के & भ̊ & $\widehat{\widehat{o}}$ & ‡্ & స઼ \\
\hline 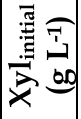 & $\vec{N}$ & $\bar{\sim}$ & 악 & $\bar{\lambda}$ & 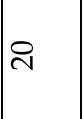 & $\stackrel{\text { 우 }}{2}$ & $\stackrel{10}{7}$ & 18 & 6 & 6 & $\sigma$ & 0 \\
\hline 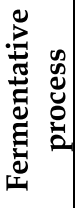 & 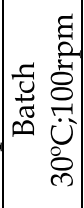 & 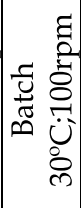 & 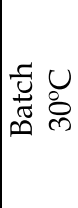 & 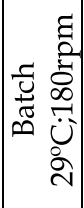 & 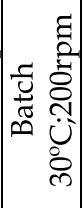 & 吾 & 竞 & 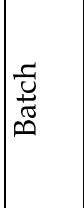 & 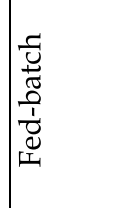 & 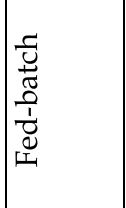 & 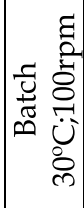 & 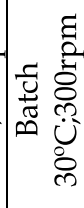 \\
\hline 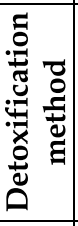 & 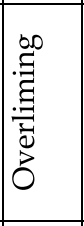 & 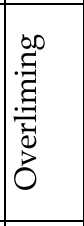 & 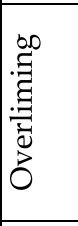 & 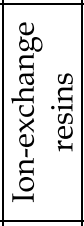 & $\begin{array}{l}\tilde{z} \\
\tilde{0} \\
\text { Z }\end{array}$ & 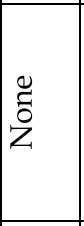 & 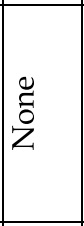 & $\begin{array}{l}\tilde{\Xi} \\
\tilde{0} \\
\text { Z }\end{array}$ & 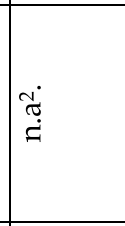 & 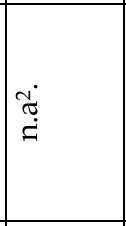 & 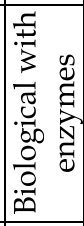 & 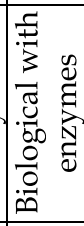 \\
\hline 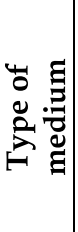 & 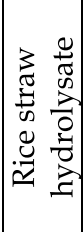 & 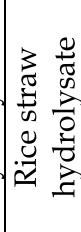 & 岕 & 岕 & 递 & 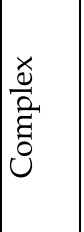 & 递 & 峞 & 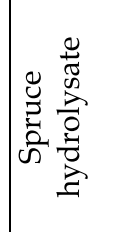 & 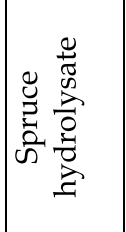 & 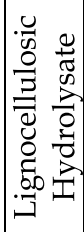 & 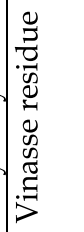 \\
\hline 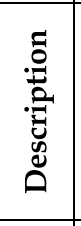 & 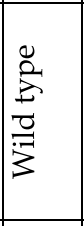 & $\begin{array}{l}0 \\
\frac{0}{0} \\
\frac{0}{0} \\
\frac{0}{4}\end{array}$ & $\mid \begin{array}{l}0 \\
\frac{0}{2} \\
\frac{a}{0} \\
\frac{0}{4} \\
\end{array}$ & 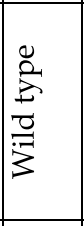 & 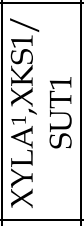 & 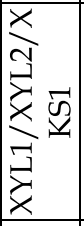 & 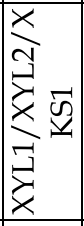 & 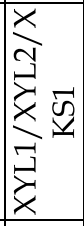 & 坣 & 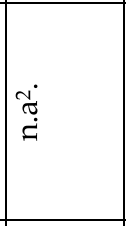 & 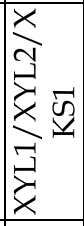 & 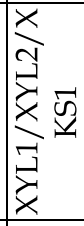 \\
\hline ڤేّ & 㑢 & 会 & 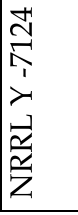 & 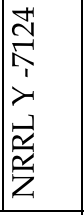 & 交 & $\sum_{2}^{20}$ & 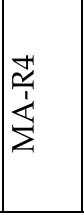 & 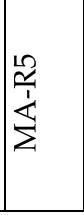 & 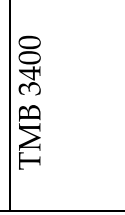 & $\begin{array}{l}0 \\
8 \\
\infty \\
0 \\
\sum \\
\sum\end{array}$ & 年 & $\underset{\mathfrak{I}}{\mathfrak{I}}$ \\
\hline 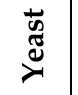 & & 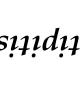 & & & & & & & & ${ }^{2} S_{S}$ & & \\
\hline
\end{tabular}

${ }^{1}$ xylose isomerase from Piromyces $s p$.

${ }^{2}$ not available

Table 7. Fermentation performance of several yeasts in different media 
Several metabolic engineering and genetic modification strategies to enhance an efficient fermentation of xylose to ethanol were studied for S. cerevisiae (Chu et al. 2007; HahnHagerdal et al. 2007; Matsushika et al. 2009). Although the genes that allow for xylose utilization are present in $S$. cerevisiae, they are expressed in low levels resulting in production rates of ethanol from xylose ten times lower than the verified for glucose as substrate (Chu et al. 2007; Hahn-Hagerdal et al. 2007). In pentose-fermenting yeasts, xylose catabolism begins with its reduction to xylitol by a NADH- or NADPH-dependent xylose reductase (XR), as seen in Fig. 9. Then, xylitol is oxidized to xylulose by NAD-dependent xylitol dehydrogenase (XDH) (Chu et al. 2007; Hahn-Hagerdal et al. 2007; Bengtsson et al. 2009). Xylulose is phosphorylated by the enzyme xylulokinase (XK) to produce xylulose-5phosphate $(\mathrm{X} 5 \mathrm{P})$. This enters in glycolytic pathway and then in the pentose phosphate pathway (PPP). The formed intermediates are converted to pyruvate in the EmbdenMeyerhof-Parnas pathway. Under anaerobic conditions, fermentation of pyruvate occurs by decarboxylation promoted by pyruvate decarboxylase to acetaldehyde which is then reduced to ethanol by alcohol dehydrogenase (Chu et al. 2007; Hahn-Hagerdal et al. 2007).

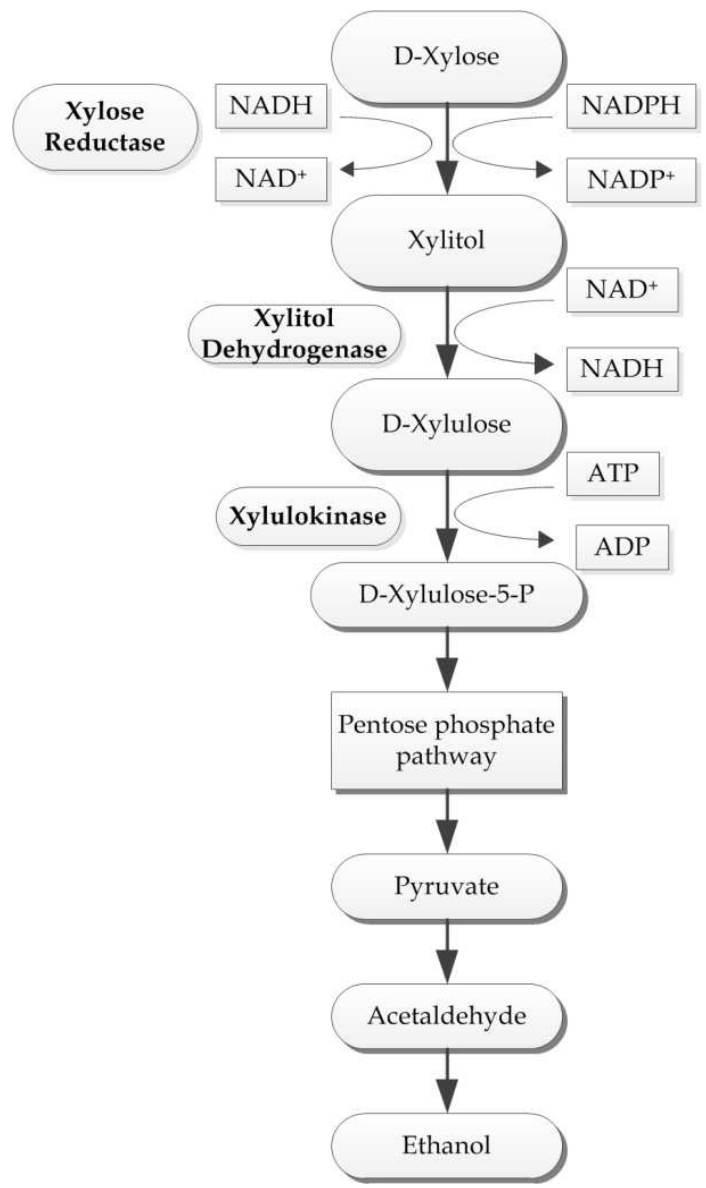

Fig. 9. Xylose metabolic pathway in yeasts (adapted from Matsushika et al. 2009) 
The most straightforward metabolic engineering strategy was the expression of a bacterial xylose isomerase (XI) gene, so that xylose can directly be converted to xylulose (Jeppsson et al. 2006). The XI gene from the thermophilic bacterium Thermus thermophilus was successfully expressed in $S$. cerevisiae, generating xylose-fermenting recombinant strains (Karhumaa et al. 2005). Also, the genes of Piromyces sp. XI were also successfully expressed in S. cereviasiae (Kuyper et al. 2003). Another possible metabolic engineering strategy consisted in expressing fungal $\mathrm{XR}$ and $\mathrm{XDH}$ genes. Stable xylose-fermenting S. cerevisiae strains were obtained by integrating the $P$. stipitis XYL1 and XYL2 genes encoding XR and $\mathrm{XDH}$, respectively, and over expressing the endogenous XKS1 gene encoding xylulokinase (XK) (Bengtsson et al. 2009; Matsushika et al. 2009). However, ethanol yield attained with these strains was far from the theoretical maximum of $0.51 \mathrm{~g} \cdot \mathrm{g}^{-1}$, as can be seen in Table 7 because the metabolic pathway stopped in xylitol. This situation was attributed to the fact that since $\mathrm{XR}$ is $\mathrm{NAD}(\mathrm{P}) \mathrm{H}$-dependent and $\mathrm{XDH}$ is strictly NAD+-dependent the relation between the two cofactors sometimes becomes unbalanced (Jeppsson et al. 2006; Chu et al. 2007; Bengtsson et al. 2009).

Wahlbom and Hahn-Hägerdal (2002) found that the addition of electron acceptors such as acetoin, furfural and acetaldehyde re-oxidized $\mathrm{NAD}^{+}$needed by $\mathrm{XDH}$ and decreased the amount of xylitol formed. Shifting the cofactor utilization in the XR step from NADPH to $\mathrm{NADH}$ was also a successful strategy for decreasing xylitol (Jeppsson et al. 2006). Since $S$. cerevisiae lacks the xylose-specific transporter, another common approach is to express in this microorganism the gene that encodes the transport of monosaccharides from $P$. stipitis (Van Vleet et al. 2009). Hence, xylose uptake occurs by facilitated diffusion mainly through non-specific hexose transporters, which have lower affinity for xylose (Matsushika et al. 2009). This approach enhanced xylose fermentation to ethanol by S. cerevisiae (Van Vleet $e t$ al. 2009).

In addition to metabolic engineering, natural selection of strains and random mutation are also alternatives to obtain improved xylose-fermentative yeasts. These evolutionary engineering approaches were successfully applied to several $S$. cerevisiae strains for effective xylose fermentation. These methods are particularly useful since they are non-invasive and can identify bottlenecks in the xylose metabolic pathway that can then be targeted to be overcome by genetic engineering (Chu et al. 2007; Matsushika et al. 2009). Chu and Lee (2007) suggested that an intense selection pressure will favour the presence of $S$. cerevisiae mutants able to grow slowly on xylose.

Recent studies have redirected their attention to the xylose-fermenting yeast, $P$. stipitis. In this case, the major issue is the inhibitors tolerance which can be critical when real raw materials are tested. Hence, an evolutionary strategy has been adopted. The strains adaptation was normally accomplished by sequential transfer of culture samples to different media composed by increasing concentrations of the residue in study (Mohandas et al. 1995; Bajwa et al. 2009; Huang et al. 2009). To accelerate the mutations, ultra violet radiation (UV) was also tested by Bajwa and co-workers (Bajwa et al. 2009).

Many challenges in ethanol production from xylose using metabolically engineered strains were being overcome. Several approaches were successfully employed to engineer xylose metabolism. Nevertheless, these approaches are insufficient for industrial bio-processes mainly due to the low fermentation rate of xylose when compared with glucose. Another bottleneck is the lack of tolerance to the major inhibitors present in lignocellulosic feedstocks. A successful fermentation of LCB hydrolysates requires not only a producing strain that consumes all the sugars present but with tolerance towards lignocellulose 
degradation products. Moreover, most of the methodologies tested were applied to defined synthetic media containing pure substrates and their applicability to real complex substrates should be validated. However, the composition of the inhibitors in raw materials as lignocellulosic wastes changes frequently and, consequently, the metabolic engineering method probably need some modifications to be applied (Hahn-Hagerdal et al. 2007; Matsushika et al. 2009). Metabolic engineering approaches to improve inhibitor tolerance were so far limited to the over expression of specific enzymes including laccase, phenylacrylic acid decarboxylase, glucose 6-phosphate dehydrogenase and alcohol dehydrogenase (Hahn-Hagerdal et al. 2007). These enzymes can transform some of the inhibitors (mainly the aromatic compounds) into products that microorganisms can assimilate.

In brief, the technical and economic issues related to the choice of fermenting microorganism are the conversion efficiency uniformity, the tolerance to inhibitors, the process requirements (aeration, temperature, $\mathrm{pH}$, sterilization) and the bioprocess licensing (Lawford et al. 1993). Further intensive studies that combine functional genomics analysis with metabolic engineering are required for developing robust yeast strains, tolerant to several inhibitors and to the variability of the substrate and with the ability to ferment xylose from lignocellulosic feedstocks, in order to produce ethanol, at similar rates as those attained with glucose, to be applied at industrial level (Chu et al. 2007; Hahn-Hagerdal et al. 2007; Matsushika et al. 2009).

\section{Biorefinery approach}

With the depletion of petroleum resources and increasing demand on energy, lignocellulose derived ethanol seems to be the future of transportation fuels. Also, it is noticeable that the integrated biorefineries, which generate chemicals, materials, fuels and energy from the biomass, would replace the current petroleum refineries, moving the world toward a carbohydrate-based economy (Gnansounou 2009).

By-products like HSSL cannot be discharged into natural basins due to environmental concerns (211 g COD.L-1) and must be processed (Evtuguin et al. 2010). The biochemical processing of HSSL is a well-known approach to produce value-added products such as SCP and ethanol, among others (Busch et al. 2006).

As seen previously, biological detoxification of HSSL by $P$. variotti was possible and the fungal biomass obtained ( $2.0 \mathrm{~g}$ biomass/g substrate consumed) can be sold as SCP, for animal nutrition. For process optimization a Sequential Batch Reactor (SBR) was chosen and the same inoculum was used during three batches to treat fresh HSSL. Each cycle was ended when the acetic acid reached a non-inhibitory concentration for $P$. stipitis and this operating strategy provided high volumes of detoxified HSSL, for subsequent bioethanol fermentation (Pereira et al. 2011). With this detoxification process as well as with the described ionexchange process (Xavier et al. 2010) HSSL can be further bioprocessed by P. stipitis, as reviewed before. The maximum concentration of ethanol attained was $8.1 \mathrm{~g} . \mathrm{L}^{-1}$ with a yield of $0.49 \mathrm{~g}$ ethanol.g sugars ${ }^{-1}$ (Xavier et al. 2010). The bioethanol produced from HSSL, regarding the aforementioned fermentation results, may be estimated as high as 100 litters per one ton of pulp (Evtuguin et al. 2010).

Biopolymers are also important value-added products that can be produced within a biorefinery concept, being capable to replace fossil-fuels based polymers. Microbial mixed 
cultures (MMC) under aerobic dynamic feeding conditions (ADF) in HSSL, can utilize acetic acid for polyhydroxyalkanoates (PHAs) production. PHAs are biodegradable plastics that can be stored intracellularly by bacteria from renewable resources. A MMC culture was selected in a SBR under ADF conditions using HSSL as substrate and was able to produce $37.7 \%$ of PHA per cell dry weight. The microorganisms were able to uptake the acetic acid and also xylose and store them as PHA. Another polymer that was possible to produce from HSSL is bacterial cellulose (BC). The majority of the cellulose available on earth is produced by plants but some microorganisms such as algae, fungi and bacteria are also able to produce an extra-cellular form of cellulose. Bacteria belonging to the genera Gluconacetobacter, Sarcina or Agrobacterium are able to produce BC. BC is highly pure, since it is not associated with hemicelluloses and lignin as in plants (Klemm et al. 2001). BC bears also unique physical and mechanical properties that arise from its tridimensional and branched nano and micro-fibrillar structure (Iguchi et al. 2000). Finally, BC shows biocompatibility, being an excellent material for biomedical applications (Carreira et al. 2011). Carreira et al. (2011) using HSSL and Gluconacetobacter sacchari was able to produce 0.29 g. $\mathrm{L}^{-1}$ of $\mathrm{BC}$ with a conversion ratio of $28 \%$ and yield of $105 \%$. Although the production of $\mathrm{BC}$ was low, when compared to the results obtained with pure compounds $\left(2.70 \mathrm{~g} . \mathrm{L}^{-1}\right.$ with glucose) these preliminary results showed that it was possible to produce BC from this kind of by-product (Carreira et al. 2011).

Even after all these bioprocesses, the remaining residues (biomass, sugars not consumed and other compounds) still represent a large amount of carbon oxygen demand $(>100$ gCOD.L-1). In this way, anaerobic digestion (AD) has shown great potential in using renewable resources such as management residues. AD is a biological process by which organic matter is transformed into methane and carbon dioxide in the absence of oxygen (Mata-Alvarez et al. 2000). The digestion process begins with bacterial hydrolysis of the input materials in order to break down insoluble organic polymers, such as carbohydrates, and make them available for other bacteria. Then acidogenic bacteria convert sugars and amino acids into carbon dioxide, hydrogen, and organic acids. These are then converted into acetic acid, along with additional hydrogen, and carbon dioxide. Finally, methanogenic microorganisms convert these products to methane and carbon dioxide (Mata-Alvarez et al. 2000). Preliminary results showed that with a MMC, volatile fatty acids (VFAs) like acetic, proprionic and n-butiric acids, can be produced using HSSL after bioethanol production. A yield of 0.15 mg COD.mg COD-1 for the acetic acid was obtained using AD. Although AD in HSSL is a research area in progress, acidification of HSSL and wastes from bioethanol production is possible. Not only the remaining sugars but also other compounds present in the HSSL were converted into VFAs.

SCP, bioethanol, PHAs, BC and VFAs are some of the value-added products that so far, can be produced from HSSL the subproduct of acidic sulphite pulping process (Fig. 10). Although yields were low for industrial implementation, most of these data are preliminary results and would be useful to optimize the process and develop new strategies towards a comprehensive utilization of by-products from sulphite pulp production thus fulfilling the environmental concerns, improving the sustainability of pulp plant and contributing also for the pulp mill profits. Optimization of all these processes is a necessary step for improving productivity for the biorefinery implementation in the industrial process and the commercial application of the value-added products. 


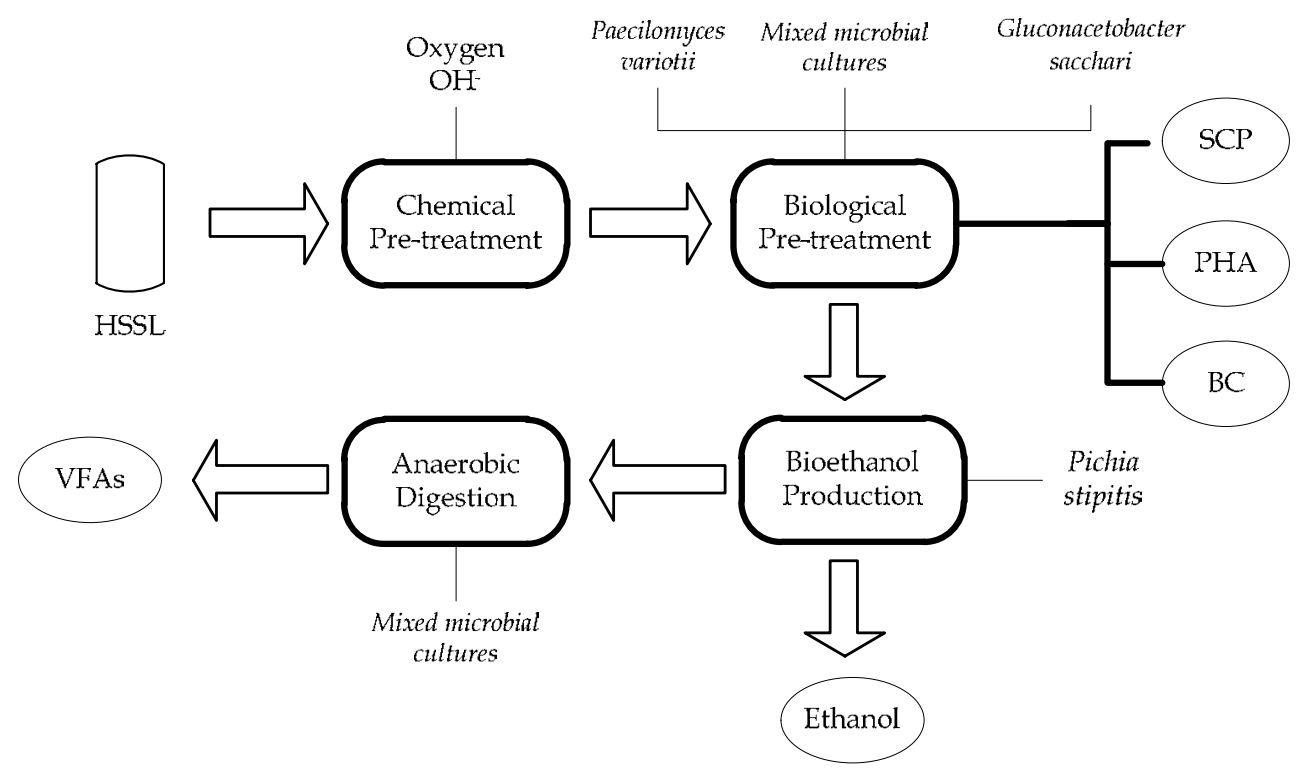

Fig. 10. Value-added products that can be produced using HSSL in the biorefinery concept

\section{References}

Alvarado-Morales, M., J. Terra, K. V. Gernaey, J. M. Woodley \& R. Gani. (2009). Biorefining: Computer aided tools for sustainable design and analysis of bioethanol production. Chemical Engineering Research \& Design, Vol. 87, No. 9A, pp. 1171-1183, ISSN 02638762.

Alvira, P., E. Tomas-Pejo, M. Ballesteros \& M. J. Negro. (2010). Pretreatment technologies for an efficient bioethanol production process based on enzymatic hydrolysis: A review. Bioresource Technology, Vol. 101, No. 13, pp. 4851-4861, ISSN 0960-8524.

Bacovsky, D., W. Mabee \& M. Worgetter. (2010). How close are second-generation biofuels? Biofuels Bioproducts \& Biorefining, Vol. 4, No. 3, pp. 249-252, ISSN

Bajwa, P. K., T. Shireen, F. D'Aoust, D. Pinel, V. J. J. Martin, J. T. Trevors \& H. Lee. (2009). Mutants of the Pentose-Fermenting Yeast Pichia stipitis With Improved Tolerance to Inhibitors in Hardwood Spent Sulfite Liquor. Biotechnology and Bioengineering, Vol. 104, No. 5, pp. 892-900, ISSN 0006-3592.

Balat, M. (2011). Production of bioethanol from lignocellulosic materials via the biochemical pathway: A review. Energy Conversion and Management, Vol. 52, No. 2, pp. 858-875, ISSN 0196-8904.

Balat, M., H. Balat \& C. Oz. (2008). Progress in bioethanol processing. Progress in Energy and Combustion Science, Vol. 34, No. 5, pp. 551-573, ISSN 0360-1285.

Bengtsson, O., B. Hahn-Hagerdal \& M. F. Gorwa-Grauslund. (2009). Xylose reductase from Pichia stipitis with altered coenzyme preference improves ethanolic xylose fermentation by recombinant Saccharomyces cerevisiae. Biotechnology for Biofuels, Vol. 2, No. 9, pp. 10, ISSN 1754-6834. 
Brehmer, B., R. M. Boom \& J. Sanders. (2009). Maximum fossil fuel feedstock replacement potential of petrochemicals via biorefineries. Chemical Engineering Research $\mathcal{E}$ Design, Vol. 87, No. 9A, pp. 1103-1119, ISSN 0263-8762.

Busch, R., T. Hirth, A. Liese, S. Nordhoff, J. Puls, O. Pulz, D. Sell, C. Syldatk \& R. Ulber. (2006). The utilization of renewable resources in German industrial production. Biotechnology Journal, Vol. 1, No. 7-8, pp. 770-776, ISSN 1860-7314.

Canilha, L., J. B. de Almeida e Silva \& A. I. N. Solenzal. (2004). Eucalyptus hydrolysate detoxification with activated charcoal adsorption or ion-exchange resins for xylitol production. Process Biochemistry, Vol. 39, No. 12, pp. 1909-1912, ISSN 1359-5113.

Cardona, C. A. \& O. J. Sanchez. (2007). Fuel ethanol production: Process design trends and integration opportunities. Bioresource Technology, Vol. 98, No. 12, pp. 2415-2457, ISSN 0960-8524.

Carreira, P., J. A. S. Mendes, E. Trovatti, L. S. Serafim, C. S. R. Freire, A. J. D. Silvestre \& C. P. Neto. (2011). Utilization of residues from agro-forest industries in the production of high value bacterial cellulose. Bioresource Technology, Vol. 102, No. 15, pp. 73547360, ISSN 0960-8524.

Chen, H. Z. \& W. H. Qiu. (2010a). Key technologies for bioethanol production from lignocellulose. Biotechnology Advances, Vol. 28, No. 5, pp. 556-562, ISSN 0734-9750.

Chen, M. L. \& F. S. Wang. (2010b). Optimization of a Fed-Batch Simultaneous Saccharification and Cofermentation Process from Lignocellulose to Ethanol. Industrial \& Engineering Chemistry Research, Vol. 49, No. 12, pp. 5775-5785, ISSN 0888-5885.

Chu, B. C. H. \& H. Lee. (2007). Genetic improvement of Saccharomyces cerevisiae for xylose fermentation. Biotechnology Advances, Vol. 25, No. 5, pp. 425-441, ISSN 0734-9750.

Cortez, D. V. \& I. C. Roberto. (2010). Individual and interaction effects of vanillin and syringaldehyde on the xylitol formation by Candida guilliermondii. Bioresource Technology, Vol. 101, No. 6, pp. 1858-1865, ISSN 0960-8524.

Delgenes, J. P., R. Moletta \& J. M. Navarro. (1996). Effects of lignocellulose degradation products on ethanol fermentations of glucose and xylose by Saccharomyces cerevisiae, Zymomonas mobilis, Pichia stipitis, and Candida shehatae. Enzyme and Microbial Technology, Vol. 19, No. 3, pp. 220-225, ISSN

Demirbas, A. (2005). Bioethanol from cellulosic materials: A renewable motor fuel from biomass. Energy Sources, Vol. 27, No. 4, pp. 327-337, ISSN 0090-8312.

Dix, N. J. (1979). Inhibition of fungi by gallic acid in relation to growth on leaves and litter. Transactions of the British Mycological Society, Vol. 73, No. 2, pp. 329-336, ISSN 00071536.

Dominguez, J., C. Gong \& G. Tsao. (1996). Pretreatment of sugar cane bagasse hemicellulose hydrolysate for xylitol production by yeast. Applied Biochemistry and Biotechnology, Vol. 57-58, No. 1, pp. 49-56, ISSN 0273-2289.

Evtuguin, D. V., M. R. B. Xavier, C. M. Silva \& A. Prates (2010). Towards comprehensive utilization of products from sulphite pulp production: A biorefinary approach. XXI Encontro Nacional da TECNICELPA / VI CIADICYL, Lisbon, Portugal 12-15 October, 2010.

Fengel, D. \& G. Wegener (2003). Wood. Chemistry, Ultrastructure, Reactions, Kessel Verlag, ISBN 3-935638-39-6, Munich, Germany. 
Gnansounou, E. (2009). Handbook of plant-based biofuels, CRC Press, ISBN 978-1-56022175-3.

Gonzalez-Garcia, S., C. M. Gasol, X. Gabarrell, J. Rieradevall, M. T. Moreira \& G. Feijoo. (2009). Environmental aspects of ethanol-based fuels from Brassica carinata: A case study of second generation ethanol. Renewable \& Sustainable Energy Reviews, Vol. 13, No. 9, pp. 2613-2620, ISSN 1364-0321.

Gray, K. A., L. S. Zhao \& M. Emptage. (2006). Bioethanol. Current Opinion in Chemical Biology, Vol. 10, No. 2, pp. 141-146, ISSN 1367-5931.

Hahn-Hagerdal, B., K. Karhumaa, C. Fonseca, I. Spencer-Martins \& M. F. Gorwa-Grauslund. (2007). Towards industrial pentose-fermenting yeast strains. Applied Microbiology and Biotechnology, Vol. 74, No. 5, pp. 937-953, ISSN 0175-7598.

Hahn-Hagerdal, B. \& N. Pamment. (2004). Microbial pentose metabolism. Applied Biochemistry and Biotechnology, Vol. 113, No., pp. 1207-1209, ISSN 0273-2289.

Helle, S. S., T. Lin \& S. J. B. Duff. (2008). Optimization of spent sulfite liquor fermentation. Enzyme and Microbial Technology, Vol. 42, No. 3, pp. 259-264, ISSN 0141-0229.

Huang, C.-F., T.-H. Lin, G.-L. Guo \& W.-S. Hwang. (2009). Enhanced ethanol production by fermentation of rice straw hydrolysate without detoxification using a newly adapted strain of Pichia stipitis. Bioresource Technology, Vol. 100, No. 17, pp. 39143920, ISSN 0960-8524.

Idriss, H. \& E. G. Seebauer. (2000). Reactions of ethanol over metal oxides. Journal of Molecular Catalysis a-Chemical, Vol. 152, No. 1-2, pp. 201-212, ISSN 1381-1169.

Iguchi, M., S. Yamanaka \& A. Budhiono. (2000). Bacterial cellulose-a masterpiece of nature's arts. Journal of Materials Science, Vol. 35, No. 2, pp. 261-270, ISSN 0022-2461.

Jeppsson, M., O. Bengtsson, K. Franke, H. Lee, B. Hahn-Hägerdal \& M. F. GorwaGrauslund. (2006). The expression of a Pichia stipitis xylose reductase mutant with higher KM for NADPH increases ethanol production from xylose in recombinant Saccharomyces cerevisiae. Biotechnology and Bioengineering, Vol. 93, No. 4, pp. 665-673, ISSN 1097-0290.

Jonsson, L. J., E. Palmqvist, N. O. Nilvebrant \& B. Hahn-Hagerdal. (1998). Detoxification of wood hydrolysates with laccase and peroxidase from the white-rot fungus Trametes versicolor. Applied Microbiology and Biotechnology, Vol. 49, No. 6, pp. 691697, ISSN 0175-7598.

Karhumaa, K., B. Hahn-Hägerdal \& M.-F. Gorwa-Grauslund. (2005). Investigation of limiting metabolic steps in the utilization of xylose by recombinant Saccharomyces cerevisiae using metabolic engineering. Yeast, Vol. 22, No. 5, pp. 359-368, ISSN 10970061.

Katahira, S., A. Mizuike, H. Fukuda \& A. Kondo. (2006). Ethanol fermentation from lignocellulosic hydrolysate by a recombinant xylose- and cellooligosaccharideassimilating yeast strain. Applied Microbiology and Biotechnology, Vol. 72, No. 6, pp. 1136-1143, ISSN 0175-7598.

Klemm, D., D. Schumann, U. Udhardt \& S. Marsch. (2001). Bacterial synthesized cellulose -artificial blood vessels for microsurgery. Progress in Polymer Science, Vol. 26, No. 9, pp. 1561-1603, ISSN 0079-6700.

Kurtzman, C. P. \& M. Suzuki. (2010). Phylogenetic analysis of ascomycete yeasts that form coenzyme Q-9 and the proposal of the new genera Babjeviella, Meyerozyma, 
Millerozyma, Priceomyces, and Scheffersomyces. Mycoscience, Vol. 51, No. 1, pp. 2-14, ISSN 1340-3540.

Kuyper, M., H. R. Harhangi, A. K. Stave, A. A. Winkler, M. S. M. Jetten, W. T. A. M. de Laat, J. J. J. den Ridder, H. J. M. Op den Camp, J. P. van Dijken \& J. T. Pronk. (2003). High-level functional expression of a fungal xylose isomerase: the key to efficient ethanolic fermentation of xylose by Sacharomyces cerevisiae? FEMS Yeast Research, Vol. 4, No. 1, pp. 69-78, ISSN 1567-1364.

Larsson, S., A. Reimann, N.-O. Nilvebrant \& L. Jönsson. (1999). Comparison of different methods for the detoxification of lignocellulose hydrolyzates of spruce. Applied Biochemistry and Biotechnology, Vol. 77, No. 1, pp. 91-103, ISSN 0273-2289.

Lawford, H. \& J. Rousseau. (1998). Improving fermentation performance of recombinant zymomonas in acetic acid-containing media. Applied Biochemistry and Biotechnology, Vol. 70-72, No. 1, pp. 161-172, ISSN 0273-2289.

Lawford, H. G. \& J. D. Rousseau. (1993). Production of ethanol from pulp-mill hardwood and softwood spent sulfite liquors by genetically-engineered Escherichia-coli. Applied Biochemistry and Biotechnology, Vol. 39, No., pp. 667-685, ISSN 0273-2289.

Lee, W.-C. \& C.-T. Huang. (2000). Modeling of ethanol fermentation using Zymomonas mobilis ATCC 10988 grown on the media containing glucose and fructose. Biochemical Engineering Journal, Vol. 4, No. 3, pp. 217-227, ISSN 1369-703X.

Lee, W., J. Lee, C. Shin, S. Park, H. Chang \& Y. Chang. (1999). Ethanol production using concentrated oak wood hydrolysates and methods to detoxify. Applied Biochemistry and Biotechnology, Vol. 78, No. 1, pp. 547-559, ISSN 0273-2289.

Lippits, M. J. \& B. E. Nieuwenhuys. (2010). Direct conversion of ethanol into ethylene oxide on copper and silver nanoparticles Effect of addition of $\mathrm{CeOx}$ and Li2O. Catalysis Today, Vol. 154, No. 1-2, pp. 127-132, ISSN 0920-5861.

Madhavan, A., S. Tamalampudi, A. Srivastava, H. Fukuda, V. Bisaria \& A. Kondo. (2009). Alcoholic fermentation of xylose and mixed sugars using recombinant \&lt;i\&gt;Saccharomyces cerevisiae\&lt;/i\&gt; engineered for xylose utilization. Applied Microbiology and Biotechnology, Vol. 82, No. 6, pp. 1037-1047, ISSN 0175-7598.

Marques, A. P., D. V. Evtuguin, S. Magina, F. M. L. Amado \& A. Prates. (2009). Chemical Composition of Spent Liquors from Acidic Magnesium-Based Sulphite Pulping of Eucalyptus globulus. Journal of Wood Chemistry and Technology, Vol. 29, No. 4, pp. 322-336, ISSN 0277-3813.

Martinez, A., M. E. Rodriguez, M. L. Wells, S. W. York, J. F. Preston \& L. O. Ingram. (2001). Detoxification of dilute acid hydrolysates of lignocellulose with lime. Biotechnology Progress, Vol. 17, No. 2, pp. 287-293, ISSN 8756-7938.

Mata-Alvarez, J., S. Macé \& P. Llabrés. (2000). Anaerobic digestion of organic solid wastes. An overview of research achievements and perspectives. Bioresource Technology, Vol. 74, No. 1, pp. 3-16, ISSN 0960-8524.

Matsushika, A., H. Inoue, T. Kodaki \& S. Sawayama. (2009). Ethanol production from xylose in engineered Saccharomyces cerevisiae strains: current state and perspectives. Applied Microbiology and Biotechnology, Vol. 84, No. 1, pp. 37-53, ISSN 0175-7598.

Mohandas, D. V., D. R. Whelan \& C. J. Panchal. (1995). Development of xylose-fermenting yeasts for ethanol production at high acetic acid concentrations. Applied Biochemistry and Biotechnology, Vol. 51, No. 2, pp. 307-318, ISSN 0273-2289. 
Mussatto, S., es, I. Roberto \& esConceição. (2001). Hydrolysate detoxification with activated charcoal for xylitol production by Candida guilliermondii. Biotechnology Letters, Vol. 23, No. 20, pp. 1681-1684, ISSN 0141-5492.

Mussatto, S. I., G. Dragone, P. M. R. Guimaraes, J. P. A. Silva, L. M. Carneiro, I. C. Roberto, A. Vicente, L. Domingues \& J. A. Teixeira. (2010). Technological trends, global market, and challenges of bio-ethanol production. Biotechnology Advances, Vol. 28, No. 6, pp., ISSN 0734-9750|1873-1899.

Mussatto, S. I. \& I. C. Roberto. (2004). Alternatives for detoxification of diluted-acid lignocellulosic hydrolyzates for use in fermentative processes: A review. Bioresource Technology, Vol. 93, No. 1, pp. 1-10, ISSN

Nigam, J. N. (2001a). Ethanol production from hardwood spent sulfite liquor using an adapted strain of Pichia stipitis. Journal of Industrial Microbiology E Biotechnology, Vol. 26, No. 3, pp. 145-150, ISSN 1367-5435.

Nigam, J. N. (2001b). Ethanol production from wheat straw hemicellulose hydrolysate by Pichia stipitis. Journal of Biotechnology, Vol. 87, No. 1, pp. 17-27, ISSN 0168-1656.

Nigam, P. (1999). SINGLE-CELL PROTEIN | Mycelial Fungi. Encyclopedia of Food Microbiology. K. R. Richard. Oxford, Elsevier: 2034-2044.

Nilvebrant, N.-O., A. Reimann, S. Larsson \& L. Jönsson. (2001). Detoxification of lignocellulose hydrolysates with ion-exchange resins. Applied Biochemistry and Biotechnology, Vol. 91-93, No. 1, pp. 35-49, ISSN 0273-2289.

Oakley, J. H. \& A. F. A. Hoadley. (2010). Industrial scale steam reforming of bioethanol: A conceptual study. International Journal of Hydrogen Energy, Vol. 35, No. 16, pp. 84728485, ISSN 0360-3199.

Olsson, L., H. R. Soerensen, B. P. Dam, H. Christensen, K. M. Krogh \& A. S. Meyer. (2006). Separate and simultaneous enzymatic hydrolysis and fermentation of wheat hemicellulose with recombinant xylose utilizing Saccharomyces cerevisiae. Applied Biochemistry and Biotechnology, Vol. 129, No. 1-3, pp. 117-129, ISSN 0273-2289.

Palmqvist, E. \& B. Hahn-Hagerdal. (2000a). Fermentation of lignocellulosic hydrolysates. I: inhibition and detoxification. Bioresource Technology, Vol. 74, No. 1, pp. 17-24, ISSN 0960-8524.

Palmqvist, E. \& B. Hahn-Hagerdal. (2000b). Fermentation of lignocellulosic hydrolysates. II: inhibitors and mechanisms of inhibition. Bioresource Technology, Vol. 74, No. 1, pp. 25-33, ISSN 0960-8524.

Panizzi, L., C. Caponi, S. Catalano, P. L. Cioni \& I. Morelli. (2002). In vitro antimicrobial activity of extracts and isolated constituents of Rubus ulmifolius. Journal of Ethnopharmacology, Vol. 79, No. 2, pp. 165-168, ISSN 0378-8741.

Parajó, J. C., H. Domínguez \& J. Domínguez. (1998). Biotechnological production of xylitol. Part 3: Operation in culture media made from lignocellulose hydrolysates. Bioresource Technology, Vol. 66, No. 1, pp. 25-40, ISSN 0960-8524.

Pereira, S. R., S. Ivanusa, D. V. Evtuguin, L. S. Serafim \& A. M. R. B. Xavier. (2011). Detoxification of eucalypt spent sulphite liquors: a process to enhance bioethanol production. Bioresource Technology, Vol. No., pp., ISSN In press DOI: 10.1016/j.biortech.2011.09.095

Rutz, D. \& R. Janssen (2008). Biofuel Technology Handbook, WIP Renewable Energies, ISBN Contract No. EIE/05/022/SI2.420009, München, Germany. 
Sanchez, O. J. \& C. A. Cardona. (2008). Trends in biotechnological production of fuel ethanol from different feedstocks. Bioresource Technology, Vol. 99, No. 13, pp. 5270-5295, ISSN 0960-8524.

Sannigrahi, P., Y. Pu \& A. Ragauskas. (2010). Cellulosic biorefineries--unleashing lignin opportunities. Current Opinion in Environmental Sustainability, Vol. 2, No. 5-6, pp. 383-393, ISSN 1877-3435.

Santos, S. G., A. P. Marques, D. L. D. Lima, D. V. Evtuguin \& V. I. Esteves. (2011). Kinetics of Eucalypt Lignosulfonate Oxidation to Aromatic Aldehydes by Oxygen in Alkaline Medium. Industrial \& Engineering Chemistry Research, Vol. 50, No. 1, pp. 291-298, ISSN 0888-5885.

Schneider, H. (1996). Selective removal of acetic acid from hardwood sulphite spent liquor using mutant yeast. Enzyme and Microbial Technology, Vol. 19, No., pp. 94-98, ISSN

Singhania, R. R., B. Parameswaran \& A. Pandey (2009). Handbook of Plant-Based Biofuels, CRC Press, ISBN 978-1-56022-175-3, Boca Raton, United States of America.

Sjöström, E. (1993). Wood Chemistry. Fundamentals and Applications, Academic Press, ISBN 0126474818, New York, USA.

Song, Z. X., A. Takahashi, I. Nakamura \& T. Fujitani. (2010). Phosphorus-modified ZSM-5 for conversion of ethanol to propylene. Applied Catalysis a-General, Vol. 384, No. 1-2, pp. 201-205, ISSN 0926-860X.

Thygesen, A., A. Thomsen, S. Possemiers \& W. Verstraete. (2010). Integration of Microbial Electrolysis Cells (MECs) in the Biorefinery for Production of Ethanol, H\&lt;sub\&gt;2\&lt;/sub\&gt; and Phenolics. Waste and Biomass Valorization, Vol. 1, No. 1, pp. 9-20, ISSN 1877-2641.

Upadhyay, G., S. P. Gupta, O. Prakash \& M. P. Singh. (2010). Pyrogallol-mediated toxicity and natural antioxidants: Triumphs and pitfalls of preclinical findings and their translational limitations. Chemico-Biological Interactions, Vol. 183, No. 3, pp. 333-340, ISSN 0009-2797.

Van Vleet, J. H. \& T. W. Jeffries. (2009). Yeast metabolic engineering for hemicellulosic ethanol production. Current Opinion in Biotechnology, Vol. 20, No. 3, pp. 300-306, ISSN 0958-1669.

Vanzyl, C., B. A. Prior \& J. C. Dupreez. (1988). Production of Ethanol from Sugar-Cane Bagasse Hemicellulose Hydrolyzate by Pichia-Stipitis. Applied Biochemistry and Biotechnology, Vol. 17, No., pp. 357-369, ISSN 0273-2289.

Vanzyl, C., B. A. Prior \& J. C. Dupreez. (1991). Acetic-Acid Inhibition of D-Xylose Fermentation by Pichia-Stipitis. Enzyme and Microbial Technology, Vol. 13, No. 1, pp. 82-86, ISSN 0141-0229.

Wang, W. \& Y. Wang. (2008). Thermodynamic analysis of hydrogen production via partial oxidation of ethanol. International Journal of Hydrogen Energy, Vol. 33, No. 19, pp. 5035-5044, ISSN 0360-3199.

Xavier, A. M. R. B., M. F. Correia, S. R. Pereira \& D. V. Evtuguin. (2010). Second-generation bioethanol from eucalypt sulphite spent liquor. Bioresource Technology, Vol. 101, No. 8, pp., ISSN 0960-8524(print) |1873-2976(electronic).

Yu, C.-Y., D.-W. Lee, S.-J. Park, K.-Y. Lee \& K.-H. Lee. (2009). Study on a catalytic membrane reactor for hydrogen production from ethanol steam reforming. International Journal of Hydrogen Energy, Vol. 34, No. 7, pp. 2947-2954, ISSN 0360-3199. 
Zhang, Y. H. P. (2008). Reviving the carbohydrate economy via multi-product lignocellulose biorefineries. Journal of Industrial Microbiology \& Biotechnology, Vol. 35, No. 5, pp. 367-375, ISSN 0169-4146. 


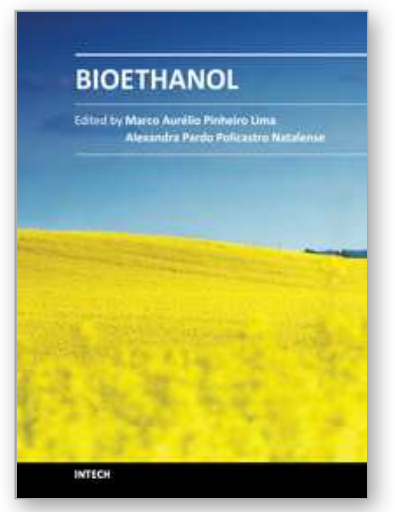

\author{
Bioethanol \\ Edited by Prof. Marco Aurelio Pinheiro Lima
}

ISBN 978-953-51-0008-9

Hard cover, 290 pages

Publisher InTech

Published online 01, February, 2012

Published in print edition February, 2012

Recent studies have shown strong evidence of human activity impact on the climate of the planet. Higher temperatures and intensification of extreme weather events such as hurricanes are among the consequences. This scenario opens up several possibilities for what is now called "green" or low carbon economy. We are talking about creating new businesses and industries geared to develop products and services with low consumption of natural resources and reduced greenhouse gases emission. Within this category of business, biofuels is a highlight and the central theme of this book. The first section presents some research results for first generation ethanol production from starch and sugar raw materials. Chapters in the second section present results on some efforts around the world to develop an efficient technology for producing secondgeneration ethanol from different types of lignocellulosic materials. While these production technologies are being developed, different uses for ethanol could also be studied. The chapter in the third section points to the use of hydrogen in fuel cells, where this hydrogen could be produced from ethanol.

\title{
How to reference
}

In order to correctly reference this scholarly work, feel free to copy and paste the following:

Daniel L. A. Fernandes, Susana R. Pereira, Luísa S. Serafim, Dmitry V. Evtuguin and Ana M. R. B. Xavier (2012). Second Generation Bioethanol from Lignocellulosics: Processing of Hardwood Sulphite Spent Liquor, Bioethanol, Prof. Marco Aurelio Pinheiro Lima (Ed.), ISBN: 978-953-51-0008-9, InTech, Available from: http://www.intechopen.com/books/bioethanol/second-generation-bioethanol-from-lignocellulosics-processingof-hardwood-sulphite-spent-liquor

\section{INTECH}

open science | open minds

\section{InTech Europe}

University Campus STeP Ri

Slavka Krautzeka 83/A

51000 Rijeka, Croatia

Phone: +385 (51) 770447

Fax: +385 (51) 686166

www.intechopen.com

\section{InTech China}

Unit 405, Office Block, Hotel Equatorial Shanghai

No.65, Yan An Road (West), Shanghai, 200040, China 中国上海市延安西路65号上海国际贵都大饭店办公楼405单元

Phone: +86-21-62489820

Fax: $+86-21-62489821$ 
(C) 2012 The Author(s). Licensee IntechOpen. This is an open access article distributed under the terms of the Creative Commons Attribution 3.0 License, which permits unrestricted use, distribution, and reproduction in any medium, provided the original work is properly cited. 